\title{
Zur Kenntnis der zur Gruppe der Tuberkelbazillen gehörenden säurefesten Mikroorganismen.
}

(Aus dem hygienischen Institut der Kgl. Universität Berlin und aus dem hygienischen Institut der Universität Zürich.)

Von Stephanie Rosenblat.

Die Entdeckung der Tuberkelbazillen ähnlichen Mikroorganismen gehört unzweifelhaft zu den interessantesten und wichtigsten Errungenschaften der Bakteriologie. Die Gruppe der sog. „Säurefesten“ beschäftigt seit Jahren viele Forscher. Die Mehrzahl der Arbeiten behandelt jedoch die erwähnten Mikroorganismen hauptsächlich von dem medizinisch-bakteriologischen Standpunkte aus, d. h. mit Rücksicht auf ihre pathogenen Eigenschaften, ihr Verhältnis zu den echten Tuberkelbazillen ${ }^{1}$ ), ihre eventuellen immunisierenden Eigenschaften gegenüber der Säugetiertuberkulose usw. Aufser diesem sozusagen mehr praktischem Interesse liefert die Untersuchung der „Säure-

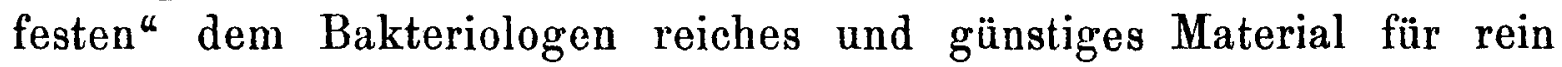
wissenschaftliche $\mathrm{Z}$ wecke. Manche der Säurefesten eignen sich dank ihren verhältnismälsig gröfseren Dimensionen und günstigen Züchtungsbedingungen besonders zu morphologischen und biologischen Studien; die Resultate können dann über ähnliche Verhältnisse bei den übrigen Bakterien manchen Aufschlufs geben. Einige lassen sich auf Grund verschiedener Eigenschaften als Übergangsformen zu den im System höher oder niedriger stehenden Pflanzenorganismen erkennen. In Anbetracht der vielen Analogieen verschiedener Formen, des grofsen Pleomorphismus und der zahlreichen Übergangsformen schien es angezeigt, die Gruppe der säurefesten Mikroorganismen zu erforschen und $\mathrm{zu}$ versuchen, in dieser Gruppe nach ihren morphologischen und kulturellen Merkmalen Arten und Varietäten zu unterscheiden.

Gegenwärtig ist der Stand dieser Frage folgender. Nach de Vries beruht der Begriff Varietät auf dem Satze, „dals auf ein einziges Merkmal keine Art gebildet werden sollte". Die Arten müssen sich in allen oder in der Mehrzahl ihrer dem Beobachter als wesentlich erscheinenden Eigenschaften - abgesehen von den Gat-

1) Ich gebrauche öfters den hergebrachten Namen Bazillus anstatt des richtigeren Bakterium einfach um die Formen zu benennen, ohne über ihre systematische Stellung dadurch irgend etwas aussagen zu wollen. 
tungsmerkmalen - unterscheiden. Der Besitz eines differenten Merkmals oder das Fehlen einer Eigenschaft, das nur auf Latenz derselben beruht, kann die Annahme einer besonderen Art nicht rechtfertigen. Wenn aber zwei Formen in ihren charakteristischen primären Merkmalen nicht wesentlich voneinander abweichen (mithin sich nur in ihren sekundären Eigenschaften unterscheiden), müssen wir sie als zwei Varietäten einer Art auffassen. Diese Definition ist nicht präzise gefalst, so dals man mitunter im Zweifel sein könnte, ob man bestimmte Formen als Varietäten einer Art oder als selbständige Arten betrachten soll. Dies erscheint aber natürlich, wenn man bedenkt, dafs manche Formen in ihrem individuellen Verhalten starken Schwankungen unterworfen sind, so dals der Grad ihrer Zusammengehörigkeit nicht leicht scharf zu begrenzen ist.

Wir sind auf diesen Gegenstand etwas näher eingegangen, da wir im folgenden wiederholt die Frage werden zu beantworten haben, ob wir in speziellen Fällen es mit Arten oder mit Varietäten zu tun haben.

Die vorliegende Arbeit soll einen Beitrag zur Kenntnis des morphologischen und biologischen Verhaltens sowie der systematischen Stellung der säurefesten Mikroorganismen bilden.

Der Übersichtlichkeit wegen wollen wir mit einer kurzen Beschreibung der einzelnen in Betracht kommenden Formen beginnen, um nachher zur Erklärung des morphologischen Baues, der biologischen Verhältnisse sowie der allgemeinen Schilderung der ganzen Gruppe überzugehen. Es wurden im ganzen 16 verschiedene Stämme untersucht, darunter sowohl obligate Parasiten als auch fakultative Saprophyten. Indem sich die verschiedenen Stämme den gleichen Züchtungsbedingungen anpassen, müssen sich die durch die natürliche Lebensweise bedingten Differenzen bis zu einem gewissen Grade verwischen, so dafs ihre wesentlichen charakteristischen Eigenschaften um so stärker hervortreten. Die Stämme gestatten so eher ihre Zusammengehörigkeit zu erkennen.

Die in Betracht kommenden Stämme sind:

Tuberkelbazillen - aus mit Sputum geimpften Meerschweinchen isoliert. Rindertuberkulosebazillen - vom kaiserlichen Gesundheitsamte. Geflügeltuberkulosebazillen - aus einer mit Geflügeltuberk. geimpften Taube isoliert.

Leprabazillus Timotheebazillus Pseudotbbaz. Petri Smegmabazillus 
Blindschleichentubbaz. \} von dem bakteriologischen Laboratorium in Grasbazillus II

5 Stämme Tobler

Korn I

Mistbazillus

Belzig

Alle Stämme wurden stets unter gleichen Bedingungen, d. h. bei denselben Temperaturen und auf denselben Nährböden gezüchtet. Bei dem Vergleich kamen nur gleich alte Kulturen in Betracht. Es ist unter anderem nach langen Versuchen gelungen, für einige Stämme ein Wachstum bei Temperaturen zu erzielen, die unterhalb oder oberhalb des bis jetzt angenommenen Temperaturoptimums liegen. Bei der Untersuchung der morphologischen Eigenschaften kamen hauptsächlich das Aussehen und die Grölse der einzelnen Formen, ihre Verzweigungen, Färbung und Säurefestigkeit in Betracht. Eingehender wurden die Fortpflanzungserscheinungen studiert. Hier sind die Resultate insofern von Wichtigkeit, als sie vielleicht zur Klärung der verschiedenen auf diesem Gebiete herrschenden Ansichten beitragen können. Unter anderem wurde auch die Kernfrage gestreift. Wir wollen diese Punkte im zweiten Teil dieser Arbeit eingehender besprechen; im folgenden mögen zunächst die einzelnen Formen kurz charakterisiert werden.

Für die Züchtung verwendete ich verschiedene feste uud flüssige $\mathrm{N} \ddot{a} \mathrm{hrböden.} \mathrm{Diese} \mathrm{sind:} \mathrm{Blutserum} \mathrm{nach} \mathrm{Löffler;} \mathrm{Blutserumglyzerin-}$ bouillon nach v. Behring (geronnenes Blutserum mit Zusatz von $3 \%$ Glyzerinbouillon). Ferner: Serum mit Proskauers Nährsalzen versetzt, Hirnagar, 5-6\% Glyzerinagar, gewöhnlicher Agar, Hesse'scher Nährboden, Gelatine, sauere und neutrale Glyzerinbouillon. Von den pflanzlichen Nährböden kamen Kartoffeln und Mohrrüben in Betracht. Die Kartoffelkeile wurden nach den verschiedenen Methoden hergestellt. 1. mit $10 \%$ Glyzerinwasser, 2. mit 10\% Glyzerinbouillon, 3. nach von Behring (die Kartoffeln wurden mit 10\% Glyzerinbouillon getränkt, in Röhrchen gebracht und mit $6 \%$ Glyzerinbouillon übergossen). Die Mohrrüben wurden desgleichen mit $10 \%$ Glyzerinwasser oder mit $10 \%$ Glyzerinbouillon versetzt. Es wurden auch alkalisch und sauer oder neutral reagirende Kartoffelnährböden hergestellt.

Für den Nachweis der Säure- oder Alkalibildung verschiedener Kulturen verwendete ich Lakmusbouillon, Lakmustraubenzuckerbouillon und Lakmusmilchzuckerbouillon.

Zur Ermittelung der reduzierenden und phosphorescierenden 
Eigenschaften kamen als Nährböden Neutralrotzuckeragar und Neutralrotgelatine zur Verwendung.

Die meisten Kulturen wurden bei verschiedenen Temperaturen gezüchtet: $22^{\circ} \mathrm{C}$, $28^{\circ} \mathrm{C}$, $37^{\circ} \mathrm{C}$. und $42^{\circ} \mathrm{C}$. In allen Fällen, wo die Bruttemperatur nicht besonders genannt ist, beträgt diese $37^{\circ} \mathrm{C}$. Um die Kulturen vor dem Austrocknen zu schützen, habe ich die Reagenzröhrchen mit Gummikappen überzogen oder mit Siegellack abgeschlossen.

Die Kulturen wurden, so lange sie lebensfähig waren (etwa 10 bis 12 Wochen) täglich untersucht.

Die für die Ausprüfung der Säurefestigkeit verwendeten Methoden sind: nach Ehrlich, Ziehl-Neelsen, Günther.

Die Methoden habe ich in folgender Weise angewendet:

Verfahren nach Ehrlich:

1. Färben in Anilinwasserfuchsin einige Minuten in dampfender Lösung;

2. Abspülen und Entfärben in $25 \% \mathrm{HNO}_{3}$ eine bis mehrere Minuten;

3. Abspülen in $70 \%$ Alkohol bis kein Farbstoff mehr abgegeben wird;

4. Nachfärbung (einige Minuten) mit Methylenblau.

Nach Ziehl-Neelsen:

1. Färbung in Karbolfuchsin über der Flamme 3 bis 5 Minuten;

2. Abspülen in $\mathrm{H}_{2} \mathrm{O}$;

3. Entfärben (10 Sekunden) in $5 \% \mathrm{H}_{2} \mathrm{SO}_{4}$ oder in $15 \% \mathrm{HNO}_{3}$;

4. Abspülen in 70\% Alkohol, bis das Präparat farblos wird;

5. Nachfärben in Löffler'scher Methylenblaulösung $1^{1 / 2}$ bis 2 Min. Nach Günther:

1. Färben mit Ehrlich'scher Anilinwasserfuchsinlösung oder mit Karbolfuchsin unter Aufkochen;

2. Entfärben (eine bis einige Minuten) in $3 \% \mathrm{HCl}$ enthaltendem Alk. abs.;

3. Nachfärben mit Methylenblaulösung.

Für die mikroskopische Untersuchung habe ich vorwiegend ein Mikroskop, System Zeifs mit Ölimmersion und Okular 4, oder Apochrom.-Immersion und Kompensationsokulare 4 und 8 (für Kernstudien) benutzt. Das Mikroskop Zeils konnte ich nicht die ganze Zeit zu meiner Verfügung haben und war daher genötigt, mich eines anderen von Winkel mit Ölimmersion und Okular 4 zu bedienen. 


\section{Abschnitt I. Morphologisches und kulturelles Verhalten einzelner Stämme.}

Wir wollen mit der Betrachtung der Tuberkelbazillen, als der bekanntesten, beginnen.

\section{Tuberkelbazillus.}

\section{Mikroskopisehes Aussehen.}

Die Tuberkelbazillen zeigen sich in jungen Kulturen als feine Stäbchen von 1,6 bis $8,4 \mu$ Länge. Sie sind gewöhnlich nicht ganz gerade gestreckt, zeigen vielmehr schwache Biegungen. Die Individuen nehmen häufig die typische Winkelstellung oder parallele Gruppierung an. Eigenbeweglichkeit fehlt. Nur selten sind die Stäbchen homogen gebaut; die etwas älteren Formen besitzen die längst bekannten endständigen Keulen und kolbige Anschwellungen, auch sieht man den Inhalt der Zelle in mehrere ungleich grofse Abschnitte zerfallen. Nicht selten kommt es $\mathrm{zu}$ fadenähnlichen Bildungen mit einfachen oder mehrfachen Verzweigungen. Das letztere findet häufig bei den älteren, aber noch wachstumsfähigen und kräftigen Kulturen statt: Um die Verzweigungen zu veranlassen sind unter Umständen besondere kulturelle Bedingungen, wie z. B. günstige Nährböden, nötig. Als bestes Material hat sich in diesem Falle die Kartoffel erwiesen. Auf diese Tatsachen werde ich bei der allgemeinen Besprechung der morphologischen und biologischen Eigenschaften noch näher eingehen.

Als die günstigsten Nährböden für die Züchtung der Tuberkelbazillen haben sich Hirnagar und Kartoffeln, und zwar die mit 10proz. Glyzerinwasser, wie auch die nach v. B e hring hergestellten Kartoffelkeile erwiesen. Weniger gute Resultate habe ich mit Kartoffelnährböden mit 10proz. Glyzerinbouillon erhalten; vielleicht ist hier die Ansammlung von Peptonen für das Gedeihen der Mikroorganismen schädlich. Auf allen sonst verwendeten Nährböden konnte Wachstum erzielt werden; sehr dürftig war es nur auf Mohrrüben.

\section{Aussehen der Kulturen.}

Bei $37-38^{\circ}$ C. erscheinen auf festen Nährböden mikroskopisch bereits nach 5-6, makroskopisch erst nach 10-14 Tagen wahrnehmbare kleine bläschenförmige, grau-weifse oder gelblich-weifse Gebilde, die dann zu trockenen, auf der Oberfläche des Nährbodens lose aufliegenden Schüppchen von starrer, brüchiger Konsistenz werden. Was die Entwicklung der Kolonieen anbetrifft, so läfst sich sowohl Höhenals auch Dickenwachstum bemerken. Das übertragene Material ver- 
gröfserte sich hauptsächlich dadurch, dafs auf seiner Oberfäche sich kleine ovale oder runde Körnchen, die sich neben- und übereinander legen, bilden. In älteren Kulturen sieht man auf der Oberfläche des Nährbodens voluminöse wasserförmige Wucherungen.

Nicht immer jedoch haben die Tuberkelbazillenkulturen das typische schuppig-trockene Aussehen. So habe ich unter anderen zwei Glyzerinagarkulturen bekommen, die eine weichere, stellenweise fast schmierige Konsistenz zeigten. Sie waren nicht auf bestimmte Partieen des Nährbodens begrenzt und bildeten einen einheitlichen ausgedehnten weifsen Belag, der demjenigen der Geflügeltuberkulosebazillen täuschend ähnlich aussah.

Auf Glyzerinbouillon wie überhaupt auf flüssigen Nährböden entwickelt sich der Tuberkelbazillus, seinem starken Sauerstoffbedürfnis entsprechend, nur auf der Oberfäche; er bildet dicke, faltige Häute. Die beschriebenen Erscheinungen stellen das Wachstumsbild bei $37-38^{\circ} \mathrm{C}$. dar. Bei $42^{\circ} \mathrm{C}$. ist das Wachstum dürftiger. Bei $28^{\circ} \mathrm{C}$. gelang es erst nach lange fortgesetzten Überimpfungen die Tuberkelbazillen auf Kartoffeln (mit 10proz. Glyzerinwasser und nach v. Behring) zum Wachstum zu bringen. Auch bei dieser Temperatur besalsen die Kulturen dasselbe typische schuppige Aussehen. Die Farbe der Kulturen wechselt stark mit den Wachstumsbedingungen. Auf diesen Punkt werde ich im biologischen Teil dieser Arbeit besonders zurückkommen. Die Kulturen erscheinen weifs-grau oder gelblichweils, in anderen Fällen aber orangegelb oder rötlich.

Der Geruch der Kulturen, besonders der älteren und der üppig gewachsenen, ist sehr fein: er erinnert an Heliotropium.

Widerstandsfähigkeit gegen Erhitzung.

Die Kulturen wurden während einer Stunde auf $50^{\circ} \mathrm{C}$. erhitzt und wurden in einigen Fällen nicht abgetötet.

\section{Rindertuberkulosebazillus.}

Mikroskopisehes Aussehen.

Der Erreger der Rindertuberkulose sieht mikroskopisch den menschlichen Tuberkelbazillen ähnlich, nur sind die Stäbchen im allgemeinen etwas plumper, auch scheinen die Keulen und Kolben häufiger vorzukommen. In älteren Kulturen verwischt sich der Unterschied sebr häufig.

Von einer Bouillonkultur wurden Kartoffel-, Glyzerinagar- und Serumkulturen angelegt. Am zweiten Tage hat das übertragene 
Material bei allen Kulturen bei $37^{\circ} \mathrm{C}$. eine gelblich-orange und bei $28^{\circ} \mathrm{C}$. eine dunkel-orange Farbe angenommen. Nach einigen Tagen trat in beiden Fällen die ursprüngliche weifs-gelbliche Färbung wieder auf.

\section{Aussehen der Kulturen.}

Aussehen der Kulturen bei $37^{\circ} \mathrm{C}$.

Kartoffelkulturen: Belag gelblich-weifs, feucht bis feucht glänzend, aus kleineren und gröfseren Knötchen bestehend.

Glyzerinagarstrich: Sehr an Tuberkelbazillen erinnernder trockener in die Höhe wachsender grau-weifser Belag. Im Kondenswasser schwacher Bodensatz.

S erum. Zunächst kleine weifse Körnchen, die dann zu einem weifsen, stellenweise glänzenden Belag konfluieren. Auf der Oberfläche des Kondenswassers eine Haut, die auf der Glaswand emporsteigt.

Bei $28^{\circ} \mathrm{C}$. ist das Wachstum auf allen Nährböden viel spärlicher.

Auf Serum ist der Belag weifs, feuchter und glänzender als bei $37^{\circ} \mathrm{C}$. Hautbildung ist auch hier vorhanden. Die Kultur erinnert sehr an eine typische Geflügeltuberkulosebazillenkultur.

Glyzerinagarstrich: das übertragene Material ist orangegelb verfärbt; nach oben hin trat ein sehr spärliches Wachstum in Form eines zarten schleimigen Belages ein.

In bezug auf das mikroskopische wie auf das makroskopische Verhalten der Rindertuberkelbazillen läfst sich eine gewisse Pleomorphität erkennen. Einerseits erinnern die trockenen schuppigen Kulturen auf Glyzerinagar an diejenigen der menschlichen Tuberkelbazillen, andererseits haben die feuchten weifsen Kulturen von weicherer Konsistenz (auf Kartoffeln und Serum) grofse Ähnlichkeit mit den Kulturen der Geflügeltuberkulosebazillen. Schon der Umstand, dals beliebige Kulturen von Menschen- und Rindertuberkulosebazillen häufig eine sehr grofse Ähnlichkeit aufweisen, ja sogar identisch sein können, deutet darauf hin, dafs die beiden Mikroorganismen nahe Verwandtschaft miteinander haben. Die Bakteriologie weist eine nicht unbeträchtliche Anzahl Versuche auf, bei welchen es gelungen ist, durch lange und fortgesetzte Adaptierung dieser beiden Formen oder Arten, wie es manche Forscher haben wollen, an passende Bedingungen die Eigenschaften, die beide Mikroorganismen voneinander unterscheiden, zu verwischen.

So kann durch fortgesetzte Passage durch den Körper des Rindes die Virulenz der menschlichen Tuberkelbazillen für das Rind gesteigert werden; die pathogenen Eigenschaften der menschlichen Tuberkel- 
bazillen werden dann denjenigen der Perlsuchtbazillen gleich. Die grofse Veränderlichkeit der beiden Formen, die, wie schon erwähnt, unter Umständen bis zum vollständigen Verschwinden der Differenzen geht, macht die Annahme zweier verschiedener Arten ganz unzulässig, da Organismen, die zu verschiedenen Arten gehören, sich in allen ihren wesentlichen Eigenschaften voneinander unterscheiden müssen. Wir wollen hier von zwei Varietäten sprechen.

\section{Geflügeltuberkulosebazillus.}

\section{Mikroskopisehes Aussehen.}

Die Erreger der Geflügeltuberkulose sind im allgemeinen zarter und kürzer als diejenigen der Säugetiertuberkulose. Der Pleomorphismus ist auch hier sehr grofs und hängt von der Beschaffenheit des Nährbodens, der Temperatur und dem Alter der Kultur ab. So zeigen die Hirnagarkulturen in der Regel längere, die Serumkulturen kürzere Formen. Bei $28^{\circ} \mathrm{C}$. gezüchtet sind sie gröfser und dicker als bei $37^{\circ} \mathrm{C}$. und $42^{\circ} \mathrm{C}$. Bei $22^{\circ} \mathrm{C}$. sehen die Stäbchen sehr typisch aus, sie sind ziemlich kurz und schlank. Im übrigen ist die Ähnlichkeit mit dem Erreger der Säugetiertuberkulose sehr grofs. Häufiges Vorkommen von Keulen und Kolben, Zerfallen des Zellinhaltes in einzelne Stücke, Verzweigungen. Säurefestigkeit ist gut ausgesprochen, kaum schwächer als bei den Säugetiertuberkelbazillen. Die Färbung ist häufig nicht homogen, indem im schwach tingierten Zelleib intensiv rote Körnchen zu sehen sind. Typische Winkelstellung und parallele Anordnung.

Auf allen eingangs erwähnten Nährböden habe ich bei verschiedenen Temperaturen Wachstum erzielt. Die tierischen Nährböden erweisen sich hierbei günstiger als die pflanzlichen. Im allgemeinen geht das Wachstum viel rascher als bei den Säugetiertuberkelbazillen vor sich. Die Temperaturgrenzen für die Züchtung liegen ziemlich weit auseinander. Die Kulturen der Geflügeltuberkelbazillen gedeihen noch sehr gut bei $28^{\circ} \mathrm{C}$, spärlicher schon bei $22^{\circ} \mathrm{C}$.

Das Wachstum der Geflügeltuberkulosebazillen verläuft wie folgt.

\section{Aussehen der Kulturen.}

In 3 bis 4 Tagen nach der Impfung bemerkt man zuerst auf der Oberfläche des festen Nährbodens kleine weilse oder gelbliche Pünktchen und Körnchen. Die Kolonien nehmen an Dicke- und Flächenausdehnung immer mehr zu: die Bläschen türmen sich übereinander und fliefsen nach einigen Wochen zusammen, um einen 
schmierigen, feuchten, weichen, bisweilen gelben, aber häufiger weifsen Belag zu bilden, der sich von dem trockenen, schuppigen Belag der Säugetiertuberkelbazillen deutlich unterscheidet.

Auf der Kartoffel ist das Wachstum üppiger und rascher als auf Mohrrüben. Die Fufsflüssigkeit wird in der Regel getrübt.

Die Mohrrübenkultur ist intensiver gelb gefärbt, als die Kartoffelkultur.

Die Gl y zerin b o u ill o n wird getrübt. Die Wände des Reagenzröhrchens scheinen wie von feinem Staub überzogen. Auf dem Boden bildet sich ein ziemlich dicker Niederschlag; auf der Oberfläche ein zartes Häutchen.

Nicht immer ist das Wachstum so typisch. Einige meiner Glyzerinagarkulturen besafsen das Aussehen und die Konsistenz der Säugetiertuberkelbazillenkulturen.

Deutlich ausgeprägt war die Analogie bei den Kulturen, für die das Material zur Impfung von einem an Geflügeltuberkulose eingegangenem Meerschweinchen entnommen wurde. (Das Tier wurde mit $10 \mathrm{ccm}$ Milzaufschwemmung von einer an Geflügeltuberkulose eingegangenen Taube geimpft.) Die Kartoffelkulturen waren intensiv gelb verfärbt. Diese wie die Glyzerinagarkulturen waren trocken, schuppig, von der Unterlage leicht abhebbar, jedoch nicht so stark zerbrechlich und spröde, wie die typischen Tuberkelbazillenkulturen. Wie bereits erwähnt, gibt es bei den Säugetiertuberkelbazillen ähnliche Übergangsformen. Auch schien die Wachstumsform sich mehr dem Charakter derjenigen der Säugetiertuberkelbazillen zu nähern, d. h. es fand eher ein Höhen- als Flächenwachstum statt.

Von vielen Autoren wird die grofse Ähnlickeit zwischen den Säugetier- und den Geflügeltuberkelbazillen besonders erwähnt. Durch Benutzung verschiedener Nährböden hat man versucht die Unterschiede im Wachstum auszugleichen. So ist es $\mathrm{F}$ is chel gelungen, die beiden Tuberkelbazillenformen auf Eiernährböden, auf dem $2 \%$ gesättigter Thymollösung enthaltenden Glyzerinagar, sowie auf Borsäureglyzerinagar zu ungefähr gleichem Wachstum zu bringen.

Nach Lubinski zeigen die Hühnertuberkelbazillen auf dem $4 \%$ enthaltenden Kartoffel-Fleischpeptonagar einen trockenen, stark körnigen, demjenigen der Säugetiertuberkelbazillen sehr ähnlichen Belag. Bei der Beschreibung der Säugetiertuberkelbazillen habe ich bereits erwähnt, dafs zwei meiner Glyzerinagarkulturen die Beschaffenheit der Geflügeltuberkelbazillenkulturen besafsen.

Nach einigen Forschern (Weber, Kossei, Heufs) gibt es 
Stämme, die, wie die Säugetiertuberkelbazillen, auf festen Nährböden trocken und faltig, auf flüssigen mit einer Oberflächenhaut wachsen so dafs sie von den üppig gewachsenen Säugetiertuberkelbazillenkulturen nicht zu unterscheiden sind.

Die Frage hinsichtlich der Verwandtschaft der Säugetier- und Geflügeltuberkelbazillen wird von den Forschern, die sich damit besonders befafsten, verschieden beantwortet. Rivolta war der erste, der sich für die Verschiedenheit der Erreger bei der Tuberkulose der Menschen und Vögel bestimmt aussprach. In demselben Sinne sprach sich Maffucci aus. Auch Straus, seine Schüler Würtz und Gamaleia und in neuester Zeit de Jong sind für die Verschiedenheit der beiden Tuberkelbazillenarten eingetreten. Robert $\mathrm{K}_{\mathbf{o c h}}$ ändert seine ursprüngliche Ansicht in diesem Sinne, dafs die Hühnertuberkelbazillen eine besondere, aber den echten Tuberkelbazillen sehr verwandte Art sei.

Die sog. Dualisten vertreten den Standpunkt, dals die beiden Formen gänzlich voneinander verschieden seien. Fine solche Annahme ist nicht stichhaltig, da die Tatsachen, auf die sich diese Ansicht stützt, nicht unzweifelhaft feststehen. So wurde als ein Unterscheidungsmerkmal das verschiedene Aussehen der beiden Kulturen angeführt. Dals dies nicht immer zutrifft, habe ich bereits nachzuweisen versucht. Als weiterer Beweis für die Zulässigkeit der Annahme, dafs Säugetier- und Geflügeltuberkulosebazillen verschiedene Arten sind, wird angeführt, dafs die Säugetiertuberkulose auf Hühner nicht übertragbar sei und dafs die Meerschweinchen bei subkutaner Impfung nicht erkranken. Auch dieser Grund ist nicht stichhaltig. Es sind schon vielfach Versuche über die gegenseitige Übertragung von Geflügel- und Säugetiertuberkulose mit positivem Erfolg gemacht worden.

Nach Nocard sind die Kaninchen für die beiden Tuberkelbazillenformen empfänglich. Oben habe ich über die Resultate der Infizierung eines Meerschweinchens mit Geflügeltuberkulose berichtet. Die Impfung gelang in gleicher Weise mit einer weifsen Maus. Gegen strengen Dualismus scheinen auch die Versuche von Nocard zu sprechen. Nocard gelang die Säugetiertuberkelbazillen für Hühner pathogen, für Meerschweinchen avirulent zu machen. Er wandte mehrmalige Passage der Säugetiertuberkelbazillen durch den Körper des Huhns an, indem er diese in Kollodiumsäckchen in die Bauchhöhle einführte. Die aus dem Kollodiumsäckchen gewonnenen Kulturen verhalten sich auch kulturell wie die Geflügeltuberkelbazillen. Die 
angeführten Tatsachen lassen die Annahme von zwei verschiedenen Arten nicht $\mathrm{zu}$, sie sprechen aber auch nicht für die vollkommene Identität der Formen, die von manchen Gelehrten eifrig verfochten wird. In neuerer Zeit behaupten von Behring und Römer auf Grund experimenteller Untersuchungen die Artgleichheit der Geflügelund Säugetiertuberkelbazillen. Ieh glaube hier auch für die Annahme zweier Varietäten eintreten zu müssen. Für Varietäten und nicht für Arten spricht sich L. Rabinowitsch in ihrer neuesten Arbeit auf diesem Gebiete aus.

\section{Widerstandsfăhigkeit gegen Erhitzung.}

Die Kulturen der Geflügeltuberkelbazillen bleiben nach einstündigem Erhitzen auf $55^{\circ} \mathrm{C}$. noch wachstumsfähig. Ein gleich langes Erhitzen auf $60^{\circ}$ ertragen sie dagegen nicht mehr.

\section{Blindschleichentuberkelbazillus.}

Sehr nahe mit den Säugetiertuberkelbazillen ist der Erreger der Blindschleichentuberkulose verwandt. Mikroskopisch unterscheidet er sich von den Säugetiertuberkelbazillen insofern, als die Stäbchen im allgemeinen kürzer und etwas dicker als jene sind. Auch kommen Verzweigungen häufiger vor, die Keulen und Kolben sind dagegen nicht so zahlreich wie bei den Säugetier- und Geflügeltuberkulosebazillen. Die GröIse einzelner Individuen variiert beträchtlich : bei $28^{\circ} \mathrm{C}$. sind die Formen häufig länger als bei anderen Temperaturen. Die Säurefestigkeit scheint hier etwas schwächer als bei den Säugetiertuberkelbazillen zu sein. Die Färbung ist wie dort nicht immer homogen.

Als charakteristisch für das Wachstum der Blindschleichetuberkelbazillen wird feuchter, glänzender, weifser Überzug auf der Oberfläche des festen Nährbodens angegeben. Bei meinen Kulturen (die Züchtungstemperatur betrug in diesem Falle $28^{\circ}$ und $22^{\circ}$ C.) war der Belag nur auf Serum, bisweilen auch auf Kartoffeln feucht und schmierig; er war weifs, gelbrosa bis orangegelb gefärbt. Die Färbung tritt übrigens in der Regel in der Nähe des Kondenswassers, also im feuchten Teile des Nährbodens auf.

\section{Aussehen der Kulturen.}

Auf Glyzerinagar und ähnlichen Nährböden ist der Belag häufig grobgekörnt, wie aus vielen Schüppchen bestehend; trocken und brüchig.

Im Kondenswasser bildet sich eine Haut, die auf der Glaswand emporsteigt. 
Die K a r t o f f e lku lt u r erinnert an die Tuberkelbazillenkulturen. Der Unterschied besteht in dem aus vielen Körnchen gebildeten Belag und in der weicheren Konsistenz. Im Fufswasser und auf der Glaswand üppige Hautbildung. Die Färbung zeigt verschiedene Übergänge von weils und gelblichweils bis orange (wie bei Grasbazillus II) und rosa.

Die Züchtungstemperatur, die bis $22^{\circ}$ angegeben wird, konnte höher gesetzt werden. So habe ich bei $28^{\circ} \mathrm{C}$. sehr üppiges und rasches Wachstum erreicht. Bei $37^{\circ} \mathrm{C}$. war die Züchtung schwieriger; erst nach wiederholter Überimpfung konnte Wachstum erreicht werden, es war natürlich nicht so üppig wie bei $22^{\circ}$ und $28^{\circ} \mathrm{C}$. In der Glyzerinbouillonkultur üppige Hautbildung.

Nach einstündigem Erhitzen auf $50^{\circ} \mathrm{C}$. bleiben die Kulturen noch lebensfähig. Einstündiges Erhitzen auf $55^{0}$ tötet sie ab.

Wie bekannt, erhielt M o eller den Erreger der Blindschleichentuberkulose, indem er der Blindschleiche menschliche Tuberkelbazillen verimpft hatte. Man könnte also diesen Mikroorganismus als einen dem Blindschleichenkörper angepalsten Tuberkelbazillus auffassen. Dennoch scheinen mir die morphologischen und kulturellen Verschiedenheiten der beiden Stämme zu grofs zu sein, um ihre Identifizierung zuzulassen. Der Umstand aber, dafs die Blindschleichentuberkelbazillen durch fortgesetzte Überimpfung und allmähliches Steigen der Züchtungstemperatur auch bei höheren Temperaturen gedeiht und ein den Tuberkelbazillen annähernd analoges kulturelles Aussehen erhält, spricht für die nahe Verwandtschaft der beiden Stämme. Wir glauben auch hier für die Annahme zweier Varietäten eintreten zu müssen. Nach Weber und Taute sollen im Moos, Algen, Wasserpflanzen der Aquarien, wie auch im Kaltblüterkörper säurefeste Stäbchen vorkommen, die mit den Tuberkelbazillen indes nicht das geringste zu tun haben. Diese Tatsache, falls sie sich bestätigt, spricht ebenfalls gegen die vollständige Identizität der beiden Formen. Dennoch darf man aus der von Weber und Taute mitgeteilten Beobachtung weitere Konsequenzen für die Artverschiedenheit der Blindschleichen und übrigen Tuberkelbazillen nicht ziehen. Für die Verwandtschaft der beiden Tuberkelbazillenstämme sprechen auch die Agglutinations- und Immunisierungsversuche. Was für die Blindschleichentuberkelbazillen gilt, gilt wahrscheinlich auch für die Schildkrötentuberkelbazillen. Ich konnte leider diese Form für meine Untersuchungen nicht heranzichen, weil sie mir nicht zugänglich war. Jedenfalls mülsten zur endgültigen Erledigung der 
Frage noch zahlreiche Impfungsversuche bei verschiedenen Tieren herangezogen werden.

\section{Leprabazillus.}

Wir haben an dieser Stelle nun auch den Lepraerreger zu betrachten. Ich richte mich hierbei vorzugsweise nach seinen pathogenen Eigenschaften. - Bekanntlich wollten verschiedene Autoren den Leprabazillus isoliert und in Reinkultur gezüchtet haben. Ob die verschiedenen Leprabazillen die wirklichen Krankheitserreger darstellen und ob sie identisch sind, ist noch fraglich. Es stand mir nur der Stamm von $\mathrm{Czaplewski}$ zur Verfügung. (In neuester Zeit soll Kedrowski den echten Lepraerreger isoliert und rein gezüchtet haben.)

\section{Mikroskopisches Aussehen.}

Was zunächst das mikroskopische Aussehen anbetrifft, so sind die Individuen in allen Kulturen bei $37^{\circ} \mathrm{C}$. mittelgrofs, bis lang, mit Verzweigungen, die bei $28^{\circ} \mathrm{C}$. auch in ganz jungen Kulturen auftreten. Kolben und Keulen sind auch hier vorhanden. Punkto Säurefestigkeit zeigen sie einen deutlichen Unterschied gegenüber allen bis jetzt besprochenen Mikroorganismen. Die Säurefestigkeit ist noch deutlich in ganz jungen Kulturen; bei älteren Kulturen und bei fortgesetzter Überimpfung nimmt sie stark ab.

\section{Aussehen der Kulturen.}

Der Lepraerreger von Czaplewski ist ziemlich schwer zu züchten. Er gedeiht gut auf Serum und Hirnagar. Das Wachstum fängt mit kleinen tautropfenähnlichen Kolonieen, die denjenigen der Geflügeltuberkulosekulturen äbnlich aussehen, an; nach und nach bildet sich ein weifser weicher bis schmieriger Belag aus. (Czaplewski beschreibt ihn als trocken schuppig und grau, - solches habe ich nicht konstatieren können.) Bei $28^{\circ} \mathrm{C}$. gedeihen im allgemeinen die Kulturen fast ebenso gut, wie bei $37^{\circ} \mathrm{C}$. Es gelang mir einige Serumund Glyzerinagarkulturen nach wiederholter Überimpfung an die Temperatur von $28^{\circ} \mathrm{C}$. so gut anzupassen, dafs sie weiterhin bei dieser Temperatur rascher und sicherer zum Wachstum, als bei $37^{\circ} \mathrm{C}$., kamen.

\section{Timotheebazillus.}

Wir gehen jetzt zur weiteren Betrachtung der den echten Tuberkelbazillen verwandten Formen über. Als erster Vertreter soll der von Moeller auf dem Timotheegras entdeckte Timotheebazillus kurz beschrieben werden. $\mathrm{Er}$ ist, was die Form und die Säurefestigkeit anbetrifft, den Tuberkelbazillen sehr ähnlich. Die Kulturen können 
auf allen von mir angewendeten Nährböden, bei allein eingangs erwähnten Temperaturen schnell zu üppigem Wachstum gebracht werden.

Aussehen der Kulturen.

Die Kulturen sehen im allgemeinen matt und trocken aus und sind von grau-gelber bis intensiv ocker-gelber Farbe. Die Kulturen auf pflanzlichen Nährböden - Kartoffeln und Mohrrüben - nähern sich in ihrer Beschaffenheit ganz besonders den Tuberkelbazillenkulturen: sie zeigen in der Regel ein schuppiges, knötchenartiges Wachstum und zwar vorwiegend in der Richtung der Höbe. Auf anderen Nährböden kommt die schuppige Konsistenz bei $28^{\circ} \mathrm{C}$. und niedrigeren Temperaturen häufiger als bei $37^{\circ} \mathrm{C}$. vor. Dafür weisen die bei $37^{\circ} \mathrm{C}$. und höher gezüchteten Kulturen reiche Quer- und Längsfältelung, die bei $28^{\circ} \mathrm{C}$. in meisten Fällen ausbleibt. Der Belag hat überall scharf umrissene Konturen. Auf Agarplatten bilden sich verschieden grofse, wenig erhabene, gezackte Kolonieen. Sie sind granuliert. Die Ausläufer der Kolonieen sind sehr zart. Auf flüssigen Nährböden, wie auf Glyzerinbouillon ist das Wachstum sehr üppig: Hockiger Bodensatz und dicke, gefaltete ockergelbe Kamhaut, die auf der Glaswand hoch emporsteigt.

\section{Widerstandsfähigkeit gegen Erhitzung.}

Das einstündige Erhitzen auf $60^{\circ} \mathrm{C}$. tötet die Kulturen ab; auf $55^{\circ} \mathrm{C}$. erhitzt bleiben sie noch wachstumfähig.

\section{Mistbazillus.}

Dem Timotheebazillus nahe verwandt scheint ein anderer von Mo eller aus dem Kuhmist isolierter säurefester Mikroorganismus, der sogenannte Mistbazillus zu sein.

Die Ähnlichkeit betrifft hier mehr das mikroskopische Aussehen beider Formen. Die kulturellen Eigenschaften des Mistbazillus können eher mit denjenigen einer anderen Form, Tobler III, verglichen werden.

\section{Mikroskopisches Aussehen.}

Die 0,9 bis $6 \mu$ langen Stäbchen haben alle charakteristischen Eigenschaften der bis jetzt beschriebenen Formen. Die Stäbchen sind häufig zu stumpfen Winkeln oder parallelen Bündeln gruppiert. Kolben und Keulen kommen zwar nicht so häufig, wie bei den Timotheebazillen vor, dafür sind die Verzweigungen öfter als dort zu beobachten. Die Verzweigungen treten schon bei ganz jungen Kulturen auf; ich habe sie bei einer drei Tage alten Glyzerinagarkultur beobachtet. Für das 
reichliche Auftreten von Verzweigungen scheint niedrigere Temperatur, wie $22^{\circ} \mathrm{C}$. bis $28^{\circ} \mathrm{C}$. günstiger zu sein. Die Säurefestigkeit ist sehr stark ausgesprochen. Die Individuen von älteren Kulturen sind bisweilen nicht ganz homogen gefärbt. Der Mistbazillus wächst gut auf allen üblichen Nährböden. Das Temperaturoptimum liegt bei $37^{\circ} \mathrm{C}$. Die Züchtung gelingt noch bei $22^{\circ} \mathrm{C}$, , das Wachstum ist bei dieser Temperatur nur dürftig. .

\section{Aussehen der Kulturen.}

Auf Agar ist das Wachstum schon nach 48 Stunden in Form von einzelnen kleinen, etwas erhabenen, glänzenden, weifsen bis gelblich-weifsen, Kolonieen deutlich zu bemerken. Die Kolonieen sind rund von einem hellen Saum umgeben. Sie fliefsen nach einiger Zeit zusammen und bilden einen üppigen, glänzenden, scharf begrenzten Belag. Nach und nach nimmt dieser bei $37^{\circ} \mathrm{C}$. eine goldgelbe, bei $28^{\circ}$ intensiv gelbe, fast ockergelbe Färbung an.

Auf Glyzerinagar entsteht bei $37^{\circ} \mathrm{C}$. eine starke Längsund noch stärkere Querfältelung. Die Falten verlaufen nach dem Mittelpunkt des Belags zu und bilden dort eine Art Knotenpunkt. Bei $28^{\circ} \mathrm{C}$. und noch niedrigeren Temperaturen ist von der Faltenbildung nicht viel, höchstens Andeutungen, zu bemerken. Im Kondenswasser bildet sich stets ein Bodensatz, auf der Oberfäche der Flüssigkeit eine dünne Haut aus. Bei $22^{\circ} \mathrm{C}$. ist das Wachstum schwach; einzelne und stellen weise zusammengeflossene Kolonien hängen schleierartig zusammen.

Auf Serum bildet sich bei allen von mir angewendeten Temperaturen ein feuchtglänzender, einheitlicher, üppiger Belag.

- Die drei Tage alte Kartoffelkultur stellt einen intensiv dunkelgelben, schmierigen, buchtig begrenzten Belag dar. Das Glyzerinwasser ist getrübt; später bildet siçh auf der Oberfläche des Fufswassers eine dünne Haut aus.

Die Glyzerinbouillon wird leicht getrübt; an der Oberfläche bildet sich eine dicke, hellgelbe, auf der Glaswand emporsteigende Kamhaut; der Bodensatz ist flockig und sehr reichlich vorhanden.

\section{Widerstandsfähigkeit gegen Erhitzung.}

Die Kulturen widerstehen einer einstündigen Erwärmung auf $60^{\circ}$, werden dagegen durch gleich langes Erhitzen auf $65^{\circ} \mathrm{C}$. lebensunfähig gemacht.

Unsere Beschreibung des Mistbazillus weicht in manchen Einzelheiten von derjenigen ab, die Moeller angegeben hat. So be- 
hauptet Moeller z. B. keine Verzweigungen bemerkt zu haben; diese sind von anderen Forschern, wie Mayer und Lubarsch, vielfach beobachtet worden. Auch habe ich, was das makroskopische Aussehen und die Entwicklung der Kulturen anbetrifft, manches abweichende Resultat erhalten. Übrigens konnte ich fast bei allen Säurefesten sowohl in dem makro- wie in dem mikroskopischen Verhalten verschiedener Kulturen manche Abweichungen von den bis jetzt bekannten Beschreibungen beobachten. Besonders ausgeprägt war dies Verhalten bei den Stämmen von Tobler. Die Ursache ist wahrscheinlich in dem Umstande zu erblicken, dafs die Kulturen, die ich erhalten habe, infolge von mehrfachen Überimpfungen ibre Natur geändert haben, da sie sich mehr an die saprophytische Lebensweise angepafst haben, während M. Tobler ihre Formen direkt aus dem Tierkörper isoliert züchtete. Diese Tatsache bestätigt noch einmal die starke Pleomorphität der Säurefesten. Um genügenden Aufschlufs über die gegenseitige Abhängigkeit der Säurefesten zu erhalten, mufs man daher die verschiedensten Lebensbedingungen studieren.

\section{Tobler III.}

Wir gehen zu den nächst verwandten Formen über und wollen zuerst den Stamm Tobler III behandeln. Wie bereits erwähnt wurde, ist dieser dem Timotheebazillus, andererseits dem Mistbazillus sehr ähnlich.

Mikroskopisehes Aussehen.

Die Individuen sind bei $37^{\circ} \mathrm{C}$. schlank, $1,2-3,0 \mu$ lang, bei $28^{\circ} \mathrm{C}$. sind sie länger. In jungen Kulturen haben sie ausgesprochene Säurefestigkeit und lassen sich nach den verschiedenen Methoden schön rot färben; in älteren Kulturen ist die Säurefestigkeit geringer. Bei $37^{\circ} \mathrm{C}$. sind die Verzweigungen nicht sehr häufig, sie treten hauptsächlich nur bei niedrigeren Temperaturen, besonders bei $22^{\circ} \mathrm{C}$. auf. Die Keulenformen sind bei $28^{\circ} \mathrm{C}$. und bei $22^{\circ} \mathrm{C}$. gut ausgebildet, bei $37^{\circ} \mathrm{C}$. überwiegen die Kolbenformen. Die Individuen ordnen sich häufig in parallele Reihen oder nehmen Winkelstellung ein. Das Temparaturoptimum liegt bei $37^{\circ} \mathrm{C}$. Der Stamm wächst aber im allgemeinen auch sehr gut bei niedrigeren Temperaturen.

\section{Aussehen der Kulturen.}

Die drei Tage alte Glyzerinagarkultur ist gelblich, feucht, glänzend scharf umrissen, mit wulstförmigen Rändern. Der Belag besteht aus vielen zusammengeflossenen, grauweifsen bis gelblichen, sehr wenig erhabenen Kolonieen von unregelmälsigen Umrissen mit 
zarten Ausläufern. Querfalten sind stark ausgebildet. In älteren Kulturon ist die Färbung intensiver, die Fältelung ist ebenfalls reichlicher. Die Falten laufen in der Mitte zu einem Knoten zusammen. Bei $22^{\circ} \mathrm{C}$. ist das Wachstum spärlich; der Belag ist graugelb, matt, sehr zart, hie und da sind einzelne gelbe Kolonieen verstreut.

Auf der Kartoffel bildet sich ein gelber schmieriger Belag. Das Glyzerinwasser wird leicht getrübt.

Die Serumkultur ist der Kartoffelkultur sehr ähnlich, jedoch nicht so üppig gewachsen.

Glyzerinbouillon wird zuerst leicht getrübt. Die Trübung verschwindet nach einiger Zeit wieder. Gelbliche Kamhaut, flockiger Bodensatz.

\section{Widerstandsfähigkeit gegen Erhitzung.}

Die Kulturen des Stammes Tobler III gehen nach einem einstündigen Erhitzen auf $65^{\circ} \mathrm{C}$. zugrunde.

Die grofse Ähnlichkeit, die M. To bler zwischen ihren Stämmen III und $V$ gefunden hat, habe ich nicht konstatieren können. Der Grund dieses Unterschiedes wird sich weiter aus der Schilderung dieser Formen ergeben.

\section{Grasbazillus II.}

Als nächster in der Reihe der Säurefesten scheint der Gra sbazillus II von Moeller zu sein, der gewissermafsen zu den noch später in Betracht zu ziehenden Mikroorganismen darstellt.

\section{Mikroskopisches Aussehen.}

Die Präparate zeigen alle typischen Eigenschaften der Säurefesten. Nur sind hier die Verzweigungen öfter als sonst zu beob. achten, auch die Stäbchen können zu recht langen, besonders bei niedrigeren Temperaturen, $28^{\circ}$ und $22^{\circ} \mathrm{C}$., Fäden auswachsen. Die Säurefestigkeit ist gut ausgesprochen, wenn auch schwächer als bei dem Timotheebazillus.

\section{Aussehen der Kulturen.}

Auf Glyzerinagar fängt das Wachstum bei $37^{\circ} \mathrm{C}$. nach zwei Tagen mit kleinen tautropfähnlichen Pünktchen an, die später zu einem feuchten, weifsgrauen leicht gekörnten und gerunzelten Belag konfluieren. Bei niedrigeren Temperaturen $\left(28^{\circ} \text { und } 22^{\circ} \mathrm{C} \text {.) }\right)^{\circ}$ tritt eine intensive, gelblichrosa und orange Färbung ein. Die einzelnen Kolonicen sind rund gezackt und zeigen ziemlich lange Ausläufer. Die Oberfäche ist rauh.

Kart offelkultur: am unteren Teile des Kartoffelkeils ist der Belag schmierig, warzig, gekörnt, von weifsgrauer Farbe, die Ränder 
sind orange gefärbt. Am oberen trockenen Teil der Kartoffel finden sich einige gelappte ovale erhabene Partieen, die eine fein granulierte orangefarbene Oberfäche haben. Einige Stellen sind noch weilsgrau, uur hie und da wie von einem orangenen Pulver bestreut. Auf der Oberfäche des Fulswassers ist eine Hautbildung bemerkbar.

Serum: Bei $37^{\circ} \mathrm{C}$. ist der Belag granuliert und netzartig, gerunzelt. Bei $22^{\circ} \mathrm{C}$. nimmt er intensive orange Farbe an, nur die Ränder bleiben milchweils. Diese sind scharf umrissen, wellig gebogen. Im Kondenswasser Bodensatz und Hautbildung.

Auf Hirnagar ist das Wachstum sehr üppig. Der Belag ist matt, grob gekörnt, stellenweise mit wurmartigen Erhöhungen versehen; zuerst weifs, später schwach orangegefärbt.

In der Glyzerin bouillon bildet sich bei $37^{\circ} \mathrm{C}$. eine üppige, gelblichweifse Kamhaut, bei niedrigeren Temperaturen nimmt sie eine intensive orange Farbe an.

Im allgemeinen erinnert der Stamm in seinem makroskopischen Verbalten an den Smegmabazillus und den Pseudotuberkulosebazillus von Petri.

Was die Lebensbedingungen anbetrifft, so braucht Grasbazillus zu seinem Gedeihen, wie die übrigen Säurefesten, den Sauerstoff. Nach einem einstündigen Erhitzen auf $65^{\circ} \mathrm{C}$. zeigt er noch Spuren von Wachstum.

\section{Widerstandsfähigkeit gegen Erhitzung.}

Durch einstündiges Erhitzen auf $70^{\circ} \mathrm{C}$. werden die Kulturen zerstört.

\section{Pseudotuberkulosebazillus Petri.}

Wie schon erwähnt, lälst sich eine Parallele zwischen Grasbazillus und Pseudotuberkulosebazillus Petri einerseits und dem Timotheebazillus andererseits ziehen.

\section{Mikroskopisehes Aussehen.}

Die Stäbchen des Petri'schen Bazillus erinnern an den Timotheebazillus, in jüngeren Kulturen sind sie aber kürzer und plumper als jene. Die Länge einzelner Individuen wechselt beträchtlich mit den Züchtungsbedingungen. So entstehen bei $22^{\circ} \mathrm{C}$. auf Serum ganz lange, fast fadenförmige Formen. Keulenbildung ist häufig, Kolben kommen etwas seltener vor. Verzweigungen sind vorhanden, wenn auch nicht so oft, wie bei Grasbazillus. Säurefestigkeit ist gut ausgesprochen. 


\section{Aussehen der Kulturen.}

Auf Glyzerinagar bildet sich bei allen Temperaturen feuchter, glänzender weils-grauer Belag; er ist gelappt und scharf umrissen. In den ersten Tagen des Wachstums sind noch hie und da einzelne fast hügelförmig erhabene Kolonieen zu bemerken. Manche zeigen in der Mitte eine Art knopfförmige Verdickung. Die Ausläufer sind lang, ziemlich dick und verzweigt. Im allgemeinen sieht die Kolonie rauh, wie aus verfilzten Fäden gebildet aus. Bei $37^{\circ} \mathrm{C}$. nimmt der Belag unter Umständen nach und nach eine gelblich-orange Färbung an; die Ränder bleiben hell. Bei niedrigeren Temperaturen ist die Färbung stets vorhanden. Die älteren Kulturen sind gerunzelt oder netzartig gezeichnet. Im Kondenswasser bildet sich ein Bodensatz; die Oberfläche des Fufswassers wird von einer Haut bezogen, die sich auf der Glaswand emporhebt.

Auf Kartoffel ist die Kultur sehr üppig, weils-grau, feucht und wulstig. Im Fufswasser Niederschlag; auf der Oberfläche des Fufswassers eine dicke Haut. Die auf dem nach v. Behring hergestellten Nährboden gezüchteten Kulturen zeigten eine trockenere Konsistenz; am unteren Teile des Kartoffelkeils war dabei eine Schuppenbildung vorhanden.

Hirnag ar: zuerst weifser glänzender Belag, der nachher leicht gelblich-rosa wird; die Ränder bleiben weifs. Bei $28^{\circ} \mathrm{C}$. ist der Belag intensiver rosa bis orange gefärbt.

Serum: feuchter, glänzender, weifs-grauer oder weifs-gelber Belag. Stellenweise schwammige Struktur.

Mohrrüben: der Belag ist üppig und weifs, dann gelb, stellenweise granuliert und warzig. Bodensatz und Hautbildung. Die Haut ist bei Mohrrübenbouillon stärker ausgebildet.

In Glyzerinbouillon bildet der Mikroorganismus auf der Oberfläche eine grau-weifse Haut. Manchmal wird die Flüssigkeit leicht getrübt. Beim Schütteln zerfällt die Haut in Krümmel, die zu Boden sinken. Für das Wachstum ist Sauerstoff notwendig.

Widerstandsfähigkeit gegen Erhitzung.

Näch einem einstündigen Erhitzen auf $65^{\circ} \mathrm{C}$. sind noch Spuren von Wachstum zu bemerken. Gleich langes Erhitzen auf $70^{\circ} \mathrm{C}$. tötet die Kulturen ab.

\section{Tobler II.}

Wir wollen jetzt zur Beschreibung des Stammes Tobler II, als des nächst verwandten, übergehen. 


\section{Mikroskopisches Aussehen.}

In ihrem mikroskopischen Aussehen unterscheiden sich diese Miskroorganismen nicht wesentlich von den übrigen Säurefesten. Die Gröfse der einzelnen Individuen ist variabel: die Länge schwankt zwischen 0,9 bis $12,6 \mu$.

Verzweigungen kommen nicht selten vor. Das Temperaturoptimum liegt bei $37^{\circ} \mathrm{C}$.

\section{Aussehen der Kulturen.}

Eine drei Tage alte Gl y z er in a gark u l t u r ist grau-weifs, saftig, glänzend mit scharf umrissenen wulstigen Rändern; der ganze Belag ist wie von einem feinen Netz zarter Fältchen durchzogen. Nach und nach nimmt die Fältelung zu. Die Längś- und Querfalten verlaufen von den Rändern gegen die Mitte radiär zu, wo sie, wie bei dem Timotheebazillus einen knotenartigen Vorsprung bilden. Der Belag ist blattartig umrissen und reichlich gezahnt. Die Kolonieen sind erhaben und mit ganz langen kräftigen Ausläufern, die miteinander anastomosieren, versehen. Im Kondenswasser flockiger Bodensatz, auf der Oberfläche des Kondenswassers schwache Hautbildung.

Die Kart offelkultur besteht aus einem grau-weifsen, feuchten fast rahmigen Belag. Im Fufswasser schwacher Bodensatz und Hautbildung.

Die Glyzerinbouillon wird an der Oberfäche von einer grau-weifsen gefalteten warzigen Haut bedeckt; auf dem Boden des Röhrchens fetziger bis flockiger Niederschlag.

Der Geruch der Kulturen Tobler II ist unangenehm, erinnert an denjenigen von Grasbazillus II.

\section{Widerstandsfähigkeit gegen Erhitzung.}

Nach einem einstündigen Erhitzen der Kulturen auf $70^{\circ} \mathrm{C}$. sind noch Spuren von Wachstum bemerkbar.

\section{Tobler IV.}

Mit Tobler II scheint die Form Tobler IV nahe Ähnlichkeit zu haben.

\section{Mikroskopisehes Aussehen.}

Diese Mikroorganismen besitzen, wie jene, eine ziemlich variable Länge von 1,2 bis $8,4 \mu$; die kürzeren Individuen bilden jedoch die Mehrzahl. Was die Säurefestigkeit anbetrifft, so stimmen meine Resultate mit den Angaben von M. Tobler nicht überein. Die Widerstandsfähigkeit gegen Alkohol und Säuren fand ich viel geringer, als bei 
den übrigen To bler'schen Stämmen. Dasselbe gilt auch für die Form Tobler I.

Eine drei Tage.alte Glyzerinagarkultur erinnert in ihrem Verhalten an die gleichartig gezüchteten Kulturen von Tobler I und Tobler II. Durch die runden knötchenförmigen Kolonieen, die Ausbildung der Ränder und die dicke Haut, die auf der Glaswand emporkriecht, erinnert sie an die ersteren. Die Kolonieen sind kleiner und dunkler, als jene, in der Mitte erhaben, an der Peripherie abgeplattet und mit zarten kurzen Ausläufern versehen. Die Ränder des Belags sind blattförmig; eine feine radiäre Fältelung läuft gegen eine dicke Mittelrippe zu.

An Tobler II erinnert der Belag durch reichliche Fältelung. Die Kultur ist bei $37^{\circ} \mathrm{C}$. schwach rosa gefärbt. Bei niedrigeren Temperaturen ist die Färbung intensiver, der Belag feuchter, fast schmierig.

Die Kartoffelkultur zeigt einen rosa gefärbten gerunzelten üppigen Belag, der zuerst feucht, dann nach und nach matt wird. Im Fufswasser üppiger Niederschlag.

Glyzerinbouillon: flockiger Bodensatz; an der Oberfläche eine grau-rosa dicke Kamhaut. Der Geruch ist sehr schwach. Das Temperaturoptimum liegt bei $37^{\circ} \mathrm{C}$. $\mathrm{Zu}$ seinem Gedeihen braucht der Mikroorganismus Sauerstoff.

\section{Widerstandsfähigkeit gegen Erhitzung.}

Die Widerstandsfähigkeit gegen Erhitzen ist geringer, als bei Tobler II: auf $55^{\circ} \mathrm{C}$. während einer Stunde erhitzt, bleiben die Kulturen noch wachstumsfähig, gehen aber durch einstündiges Erhitzen auf $60^{\circ}$ C. zugrunde.

\section{Tobler I.}

Mikroskopisehes Aussehen.

Die Länge der Individuen variiert zwischen 0,3 und $3,6 \mu$, - die kürzeren Formen überwiegen. Sie sind ziemlich schlank, leicht gekrümmt. Verzweigungen kommen selten vor. Wie bereits erwähnt wurde, ist die Säurefestigkeit schwach. Im übrigen zeigt der Stamm die typischen Merkmale der Säurefesten: keulige Anschwellungen, Formen mit intensiver tingierten Körnchen usw.

Aussehen der Kulturen.

Auf Glyzerinagar bildet Tobler I bei $37^{\circ} \mathrm{C}$. einen rötlichen, trockenen, scharf umrissenen, granulierten Belag. Die Kolonieen sind 
ziemlich grofs und tief gezackt, in der Mitte erhaben, wo sie einen dunklen Kern zeigen. Die Oberfläche der Kolonieen sieht gekörnt, wie pigmentiert, aus. In älteren Kulturen ist die Faltenbildung stärker, die Knötchen wachsen in die Höhe und erheben sich über das Substrat. Auf der Oberfläche des Kondenswassers bildet sich eine üppige rötliche Haut aus, die auf der Glaswand emporkriecht. Bei niedrigeren Temperaturen ist die Kultur feuchter und glänzender als bei $37^{\circ} \mathrm{C}$., die Fältelung ist viel schwächer ausgeprägt, auch die Haut auf der Oberfläche des Kondenswassers ist dürftiger, als dort.

Auf der Kartoffel bildet sich ein intensiv gefärbter, rötlicher, feuchter, unregelmälsig begrenzter Belag aus, - mit stellenweise knötchenartigen Unebenheiten. Das Fulswasser bleibt klar, an seiner Oberfläche entwickelt sich eine dünne, gekörnte, leicht zerreifsbare Haut, die sich auf der Glaswand emporhebt.

Glyzerinbouillon: rötliche gekörnte Haut, die an der Glaswand hoch emporsteigt; der Bodensatz wird aus den von der Haut sich fortwährend ablösenden Schuppen gebildet. Der Geruch ist schwach, erinnert an den Geruch bei Timotheebazillus.

Widerstandsfähigkeit gegen Erhitzung.

Die Widerstandsfähigkeit gegen Erhitzen ist ziemlich grofs; erst ein einstündiges Erhitzen auf $65^{\circ}$ C. tötet die Kulturen ab.

Die tinktoriellen Eigenschaften und das Aussehen der meisten Kulturen dieses Stammes weichen fast durchgängig von dem Verhalten ab, das M. Tobler angibt. Wie bei Tobler III kann auch hier als Ursache der beobachteten Differenz allmähliche Anpassung der von mir untersuchten Stämme an die saprophytische Lebensweise angesehen werden. Diese Erklärung erscheint um so begründeter, da die von mir gezüchteten Kulturen im wesentlichen mit dem Aussehen der Kulturen, die M. P otet beschreibt, der sie gleichfalls als Saprophyten übernahm, übereinstimmen. Aus diesem Grunde mulste ich eine andere Gruppierung der T obler'schen Stämme, als M. Tobler selbst, anwenden.

\section{Tobler V.}

In unserer Darstellung kommen wir erst jetzt zur Behandlung der Stämme Tobler V und Korn I, obwohl sie mehr Analogie mit Tobler II und mit den Moeller'schen Formen, als mit den zuletzt betrachteten aufweisen.

\section{Mikroskopisehes Aussehen.}

Bei Tobler $\mathrm{V}$ begegnen wir wieder häufig recht langen Individuen von $1,2-16,8 \mu$. Die längeren Formen kommen häufiger bei 
$37^{\circ} \mathrm{C}$. als bei $28^{\circ}$ und $22^{\circ} \mathrm{C}$. vor. Verzweigungen konnte ich in den Präparaten oft beobachten. M. Tobler will sie in ihren Kulturen vermilst haben. Auch habe ich eine gut ausgeprägte Säurefestigkeit sowohl in älteren wie in jungen Kulturen konstatieren können, während M. Tobler die Säurefestigkeit nur für ganz junge, zwei Tage alte Kulturen angibt. Die Stäbchen sind ziemlich plump, oft gekrümmt und zeigen alle bekannten Anordnungen der übrigen Säurefesten. Die kolbigen Anschwellungen sind bei niedrigeren Temperaturen häufiger als bei $37^{\circ} \mathrm{C}$.

\section{Aussehen der Kulturen.}

Die drei Tage alte Glyzerinagarkultur ist weils-grau, matt, hie und da kleine matte, mehr oder weniger runde Partieen, die eine Vertiefung und einen ringförmigen Wall erkennen lassen. Von den Rändern des Belages geht eine feine radiäre Streifung aus. Aufserdem besitzt der Belag eine reiche Quer- und Längsfältelung. Die Faltenbildung nimmt mit dem Alter der Kultur zu.

Auf der Oberfläche des Kondenswassers üppige weifse Haut. Bei niedrigeren Temperaturen ist das Wachstum spärlicher. Bei $22^{\circ}$ C. erinnert die Kultur an Tobler III. Der Belag besteht aus vielen weifsen glänzenden Kolonien, die stellenweise konfluieren. Die Kolonieen sind mehr oder weniger rund, flach; einige sind stellenweise gezackt, mit zarten Ausläufern.

Kart offelkultur: Bei $37^{\circ} \mathrm{C}$. üppiger grau-weifser trockener Belag mit körniger Zeichnung am unteren Teile des Keiles und unregelmälsiger buchtiger Begrenzung. Das Fulswasser ist klar; von seiner Oberfläche hebt sich eine stark gefaltete Haut auf der Glaswand empor. Von dieser lösen sich Fetzen ab und sinken zu Boden. Bei niedrigeren Temperaturen ist das Wachstum spärlich, die körnige Zeichnung bleibt aus.

Glyzerinbouillon: weifs-graue üppige Haut; Bodensatz.

Widerstandsfähigkeit gegen Erhitzung.

Auf $60^{\circ}$ C. während einer Stunde erhitzt, gehen die Kulturen zugrunde.

Mit Tobler V stimmt in mancher Beziehung der Stamm Korn I überein.

\section{Korn I.}

\section{Mikroskopisehes Aussehen.}

Die Länge einzelner Individuen variiert zwischen 1,2 und $18,0 \mu$. Bei $28^{\circ} \mathrm{C}$. und $22^{\circ} \mathrm{C}$. werden die Stäbchen kürzer und plumper, 
als bei $37^{\circ} \mathrm{C}$. Die Enden sind meistens abgerundet, angeschwollen. Die typischen Kolben kommen am häufigsten bei den ganz kurzen Formen vor. Verzweigungen sind oft zu beobachten, auch kommen granulierte Individuen vor. Im allgemeinen weisen sie in ibrem mikroskopischen Aussehen grofse Ähnlichkeit mit Tobler V auf.

\section{Aussehen der Kulturen.}

Glyzerinagarkultur (drei Tage alt). Der Belag ist scharf umrissen, die Ränder vom Belag deutlich abgegrenzt, radiär gestreift. Hie und da einzelne runde Kolonieen, die ein wenig erhaben und mit zarten Ausläufern versehen sind. Der Belag ist wie von einem feinen Netz durchzogen. In älteren Kulturen ist der Belag feucht, einheitlicher und gefaltet.

Bei $28^{\circ} \mathrm{C}$. ist die Faltenbildung noch stärker ausgesprochen. Bodensatz und Hautbildung auf der Oberfläche des Kondenswassers.

Die Kart offelkultur zeigt besonders grofse Ähnlichkeit mit der Kartoffelkultur von Tobler V. Grau-weilser, trockener Belag. Auf der Oberfläche des Fulswassers eine gut ausgebildete Haut, die auf der Glaswand emporsteigt.

Glyzerinbouillonkultur: weifs-graue, trockene, gefaltete Kamhaut. Bodensatz üppig.

Das Temperaturoptimum von Korn I liegt bei $37^{\circ} \mathrm{C}$. $\mathrm{Zu}$ seinem Gedeihen braucht er Sauerstoff.

\section{Widerstandsfähigkeit gegen Ephitzung.}

Auf $60^{\circ}$ C. während einer Stunde erhitzt, gehen die Kulturen zugrunde.

\section{Smegmabazillus.}

\section{Mikroskopisehes Aussehen.}

Eine Sonderstellung in der Gruppe der Säurefesten nimmt der Smegmabazillus ein, welcher den Diphtheriebazillen nahe steht. Morphologisch sind die Smegmabazillen kurze, plumpe Gebilde oder schlanke gerade, selbst gekrümmte Stäbchen. Auch längere bis ganz lange (selten) Formen kommen vor, je nach der Beschaffenheit des Nährbodens. So bestehen die auf Kartoffel und Hirn gezüchteten Kulturen aus längeren Individuen. Kolben und Keulen kommen vor; Verzweigungen sehr selten. Die Färbung ist wie bei den übrigen Säurefesten häufig nicht homogen. Die Widerstandsfähigkeit gegen Alkohol und Säuren ist viel geringer, als bei Tuberkelbazillen. Gegen Säuren ist die Resistenz wesentlich gröfser, als gegenüber Alkohol. Die Kulturen 
sind im allgemeinen denjenigen von Pseudotuberkulosebazillus Petri sehr ähnlich.

Der Smegmabazillus gedeiht gut und rasch bei allen von mir angewandten Temperaturen.

\section{Aussehen der Kulturen.}

Auf Glyzerinagar wie auf Agar bildet der Smegmabazillus zuerst einen weifs-grauen, feuchten Belag. Die einzelnen Kolonieen sind in der Mitte erhaben, gezackt, mit feinen seitlichen Ausläufern. Nach und nach nimmt der Belag eine gelblich-orange Färbung an, die bei niedrigen Temperaturen intensiver wird. Bei $37^{\circ} \mathrm{C}$. bleibt die Färbung in den meisten Fällen ganz aus. Im Kondenswasser flockiger Niederschlag.

Auf Kar toffel n wie auf Mohrrüben ist das Wachstum üppig. Der Belag ist bei jungen Kulturen weich, schmierig und feucht, in älteren trockener, warzenförmig oder bestehend aus vielen Knötchen und Schüppchen, die neben- und übereinander sich türmen. Die Knötchen scheinen auf der Unterlage wie auf einem Stiel zu sitzen und zeigen in der Mitte eine kreisförmige Einbuchtung. Während die Mohrrübenkultur weils oder schwach gelb ist, zeigen die Kartoffelkulturen verschiedene Farbennuancen. Am schwächsten ist die Färbung bei den Kartoffelglyzerinwasserkulturen, etwas intensiver bei Kartoffelbouillon, am stärksten (gelborange, an die Färbung von Timotheebazillus erinnernd) auf dem nach v. Behring hergestellten Kartoffelnährboden.

Bei allen Kulturen bildet sich an der Oberfläche des Fufswassers eine üppige gefaltete Haut.

Auf Hirnagar und Serum besitzen die Kulturen eine ziemlich trockene, schuppige Konsistenz. Fältelung ist auch hier vorhanden.

In Glyzerinbouillon bildet sich eine üppige, gefaltete, auf der Glaswand emporsteigende weils-gelbe Kamhaut; flockiger Bodensatz. Beim Schütteln heben sich vom Boden krümmelige Wolken auf. Bei jungen Kulturen ist die Flüssigkeit manchmal trübe.

\section{Abschnitt II. Morphologischer Bau der säurefesten Mikroorganismen.}

Die durchgeführte Schilderung der säurefesten Stämme läfst uns eine ganze Anzahl charakteristischer Merkmale, die ihnen gemeinsam sind, erkennen. Obwohl die genannten Formen auch sonst noch grofse Ähnlichkeit aufweisen, ist es doch nicht möglich sie miteinander zu identifizieren. Wir müssen sie daher in einer Gruppe zusammen- 
fassen, der im Pflanzensystem eine ganz bestimmte Stellung zuzuweisen ist.

Bevor ich auf diese Frage eingehe, will ich zuerst das morphologische und biologische Verhalten der säurefesten Mikroorganismen an Hand einiger dazu erwählten Formen besprechen.

Nachdem die Morphologie der Bakterienzelle eingehender studiert und ihre weitgehende Ähnlichkeit mit jeder pflanzlichen Zelle erkannt wurde, lag es nahe hier dicselbe hohe Differenzicrung des Zellinhaltes zu vermuten. Theoretisch ist die Frage nach dem Bau der Bakterien leicht zu lösen. Die vitalen Funktionen dieser Gebilde sind so weit differenziert, dafs sie unbedingt eine hohe morphologische Differenzierung voraussehen lassen. Bekanntlich sind nach den neuesten Forschungen alle Eigenschaften der lebenden Zellen Äufserungen der vereinigten Tätigkeit von Kern und Protoplasma. Es gibt keine normale Funktion im Leben der Zelle, bei der einer dieser Bestandteile ausgeschaltet werden könnte, obwohl es manche Lebensäufserungen gibt, bei denen einer von ihnen mehr als der andere beteiligt ist. So scheint der Kern für den Prozefs des Wachstums sowie der Vermehrung der Zelle die wichtigere Rolle zu spielen. Im Bau der Mikroorganismen, die in ihren Lebensäufserungen mit den übrigen pflanzlichen Zellen übereinstimmen, dürfte deshalb eine ähnliche Differenzierung des Zellinhaltes zu erwarten sein. Es ist einleuchtend, dals je kleiner ein'Organismus ist, desto feiner sein Bau sein mufs, denn hier müssen sich ja alle Elemente der vegetativen, reproduktiven und sensitiven Tätigkeit im Raume einiger Mikromillimeter zusammenfinden. Rein strukturell steht eine Bakterienzelle viel höher, als die meisten Zellen der höheren Pflanzen.

\section{Bau der Bakterienzelle.}

Die verschiedensten auf diesem Gebiete herrschenden Meinungen, die in zahlreichen Veröffentlichungen ihren Ausdruck gefunden haben, haben neuerdings zu der grölsten Verwirrung geführt. Zahlreich sind die Arbeiten, die das Vorkommen von Zellkernen, ja überhaupt jeder weiteren Differenzierung des Protoplasten der niederen Mikroorganismen verneinen.

Von neueren Forschern tritt Bütschli am meisten für die Kernnatur des Centralkörpers ein. Neuerdings haben sich auch Kohl und Hegler dafür ausgesprochen. Auch nach Ruzička besteht die Bakterienzelle zum gröfsten Teil aus Kernsubstanz.

Die Beobachtungen; die ich gemacht habe, lassen sich mit der ${ }_{n}$ Centralkörpertheorie ${ }^{4}$ schwer in Einklang bringen. Die Differen- 
zierung in Rindenschicht und Centralkörper, geschweige denn eine irgend wie erkennbare Struktur des letzteren, konnte ich nicht feststellen. Wohl aber habe ich bei allen Stämmen, sowohl bei jüngeren als bei älteren Individuen das Vorhandensein von Körnchen konstatiert. Auf die Kernnatur dieser Gebilde schliefse ich nicht nur aus ihren tinktoriellen Eigenschaften, die sie mit dem Kernchromatin teilen, sondern auch aus der Rolle, die sie in den Funktionen der lebenden Zelle spielen.

In jungen Formen, meist in der Einzahl im Centrum vorhanden, treten sie in älteren Kulturen reichlicher auf. Dieser Umstand bildete häufig einen der Haupteinwände gegen die Kernnatur der betreffenden Gebilde. Der Einwand ist leicht zu widerlegen: man braucht nur der nicht seltenen Fälle zu gedenken, wo auch bei den sonstigen Pflanzen mehr als ein Kern vorkommt.

Ich glaube in der Vermehrung der „Körnchen“ ein Moment zu erblicken, das mit der Fortpflanzung der Zelle in Zusammenhang steht. Die Körnchenvermehrung scheint nämlich ein Vorstadium der darauffolgenden "Fragmentation", eines Vorganges, den ich weiter unten behandeln werde, darzustellen. Die Tatsache, dals die Zellen, die mehrere Körnchen enthalten, in ebenso viele „Fragmente" zerfallen, mithin jedes Fragment, das des weiteren Wachstums fähig ist, ein „Körnchen" enthält, mufs auf den Gedanken führen, dafs die „Körnchen" für die Lebenstätigkeit der Zelle unentbehrlich sind. Ich konnte fast regelmälsig in der Nähe von derjenigen Stelle des Fadens, wo eine Verzweigung ansetzte, wo also intensiveres Wachstum stattfand, ein Körnchen nachweisen. In einem Fall, wo ich die vitale Färbung mit stark verdünntem $(1: 10000)$ Methylenblau bei Smegmabazillen unternahm, sah ich, wie das einzige vorhandene Körnchen sich in zwei Hälften teilte, die nach den entgegengesetzten Polen des Stäbchens gelangen. Nachdem sich in der Mitte eine deutliche Scheidewand gebildet hatte, zerfiel das ganze in zwei Stäbchen mit je einem distinkten Körnchen. In welcher Weise der Vorgang vor sich ging, konnte ich mit den mir zur Verfügung stehenden Mitteln nicht feststellen. Auf den Vorgang der Fortpflanzung der Mikroorganismen komme ich noch später ausführlicher zu sprechen, an dieser Stelle mögen die wenigen Worte über die Rolle, welche die Körnchen dabei spielen, genügen.

Färbungsmethoden für den Nachweis der Körnehen.

Was die tinktoriellen Eigenschaften der Körnchen anbetrifft, so kann man die letzteren mit den verschiedensten Kernfärbungsmethoden 
nachweisen. Als geeignet haben sich zahlreiche Methoden erwiesen. So die von Meyer für die Kernfärbung angegëbene Formolfuchsinmethode, desgleichen seine Rutheniumrotmethode $(0,02$ Teile Rutheniumrot, 6 Teile Wasser, 2 Teile 95proz. Alkohol). Die Färbung mit Delafield'schem Hämatoxylin ergibt ebenfalls sehr gute Resultate: zur Erzielung der vollen Wirkung müssen die Präparate 24 Stunden in der Lösung bleiben. Ich habe ferner die R oman o w ski'sche Kernfärbungsmethode mit der von v. Wasielewski angegebenen Modifkation geübt.

Die bei dieser Methode in Frage kommenden Lösungen sind: Stammlösungen: I. 1\% Eosin extra BA Höchst,

\section{II. $1 \%$ Methylenblau medicinale pur. Höchst.}

Im Wasserbad gelöst, nicht filtriert:

Romanowski I: $1 \%$ Eosinlösung, d. h. Stammlösung $1: 10$.

n II: 1\% Methylenblaulösung: (Stammlösung) 20,0,

Polychromes Methylenblau (Unna) 40,0.

Zur Färbung: $2 \mathrm{ccm}$ von Romanowski I,

+7-8 Tropfen von Romanowski II.

$1 / 2$ Stunde färben, erst in Wasser ansehen. Diese Methode ergibt positive Resultate, ist aber zu umständlich. Eine Überfärbung lälst sich kaum vermeiden. In diesem Fall ist es gut, die Differenzierungsflüssigkeit (Alkohol $96 \%=120,0$ Teile, Eosin $1 \%=2,0$ Teile, Acid. acet. gt. $=5$ ) nur ganz kurze Zeit, höchstens ein paar Sekunden einwirken zu lassen. Sehr schöne Bilder liefert die vitale Färbungsmethode; insbesondere die Methode des Durchsaugens der Farblösung. Die letzte arbeitet überhaupt sehr zuverlässig. Für die vitale Färbung verwendet man am besten eine stark verdünnte $(1: 10000)$ wässerige Methylenblaulösung oder milchsaueres Methylenblau nach Ficker $(1: 10000+2 \mathrm{ccm}$ ac. lact. pur.). Verdünntes Löffler'sches Methylenblau eignet sich für diesen $Z_{w e c k}$ auch sehr gut. Die verschiedenen Handelspräparate von Methylenblau wirken verschieden. So habe ich mit einer verdünnten Löffler'schen Methylenblaulösung Metachromasie der Körnchen erhalten, wobei die Körnchen sich schön rot färbten. Bekanntlich ist in diesem Falle als färbende Substanz der roten Körnchen das Methylenazur anzusehen. Die Körnchen lassen sich gut auch nach vorangehendem Eintrocknen des Präparates, oder Fixieren und Behandeln mit Alkohol färben. Sie können weiter mit Safranin, wie es für den Kernnachweis in den pflanzlichen Zellen benutzt wird, mit Jodjodkalium oder nach der Methode von $\mathrm{N}$ e isser deutlich gemacht werden. Eine mehrwöchentliche Pepsinverdauung greift die Körnchen 
nicht an. Durch Einwirkung von Eau de Javelle, 65\% Chloralhydrat oder $2 \%$ Kalilauge werden sie nicht zerstört. In älteren Kulturen, die ihre Säurefestigkeit bereits eingebülst haben, treten die „Körnchen“ auch bei der gewöhnlichen Tuberkelbazillenfärbung in schwaich tingiertem Zelleib deutlich. zum Vorschein.

Die Eigenschaften der Körnchen, die im obigen geschildert wurden, scheinen den Schlufs zu rechtfertigen, dafs sie alle wesentlichen Charakteristika der echten Zellkerne teilen. Ob die „Körnchen ${ }^{4}$ die echten Kerne sind, oder ob sie nur Chromatinkörnchen im richtigen Kern, dem Centralkörper, darstellen, diese Frage muls noch offen bleiben, ich wage nicht darüber ein endgültiges Urteil auszusprechen. Es mufs noch hervorgehoben werden, dafs der gröfste Teil des Schizophyceenmaterials, das Bütschli, Hegler u. a. für ihre Untersuchungen benutzten, aụs Spaltalgen bestand. Hegler arbeitete hauptsächlich mit Anabaena, einer Nostocacee. Als weitere Objekte dienten vielfach verschiedene Oscillarien. Die Resultate dieser Forscher können nicht als entscheidend betrachtet werden, denn es ist nicht ganz unwahrscheinlich, dafs trotz der engen Verwandtschaft der Schizomyceten mit den Spaltalgen, die einschlägigen Verhältnisse doch etwas anders liegen können.

Auf Grund meiner Untersuchungen komme ich zur Annahme, dafs die Körnchen mit den Zellkernen in schr naher Beziehung stehen.

Die nächste Frage, die bei der Untersuchung der Morphologie der "Säurefesten" von Wichtigkeit ist, ist das Vorhandensein oder Fehlen der Verzweigungen und der Vorgang der Vermehrung, und dies um so mehr, als hauptsächlich von diesem Verhalten eine Klassifizierung der Formen abhängig gemacht wird. Wie ich schon bei der Besprechung einzelner Stämme erwähnt habe, konnte ich bei allen Verzweigungen feststellen; sehr dürftig waren sie bei Smegmabazillen.

\section{Verzweigungen.}

Lange Zeit hat man das Vorkommen von Verzwcigungen für Tuberkelbazillen in Abrede gestellt. Nocard und Roux, Metschnik off, Klein, Maffucci, Fischel haben auf das Vorhandensein von verzweigten Fäden in Tuberkelbazillenkulturen aufmerksam gemacht. Die fünf erstgenannten Forscher fanden die Verzweigungen lediglich bei den Hühnertuberkulosebazillen, erst Fischel war es, der sie bei den Säugetiertuberkelbazillen nachwies.

Gegen die Deutung der Verzweigungen bei Tuberkelbazillen als echter Wachstumsformen wird vielfach der Umstand herangezogen, 
dafs diese in alten Kulturen und zwar im Bodensatz oder in der Fufsflüssigkeit, wo der Sauerstoffzutritt erschwert ist, also die Lebensbedingungen besonders ungünstig sind, vorkommen. Man hat deshalb die Verzweigungen als Degenerationsprodukte, Involutionsformen gedeutet. Dieser Einwand erscheint mir nicht stichhaltig. Das Auftreten von Vorzweigungen in alten Kulturen unter ungünstigen Lebensbedingungen ist in der Regel nicht häufiger, als in jungen kräftigen Kulturen. So habe ich in ganz jungen ( $7-8$ Tage alten), also noch weiterer Entwicklung fähigen Agarkulturen Verzweigungen beobachtet. Ich habe sie weiter im Sputum vereinzelt gefunden: in mehreren Dutzenden von Präparaten, die ich untersucht hatte, habe ich derer drei oder vier angetroffen. Am häufigsten kommen die Verzweigungen in Kartoffelkulturen vor. Wie bei den Tuberkelbazillen, sind die Verzweigungen auch bei den übrigen Säurefesten vorhanden. Am günstigsten für das Auftreten der Verzweigungen sind in den meisten Fällen die festen Nährböden, besonders Kartoffel, Serum, Hirnagar.

Die Temperatur bleibt auch nicht ohne Einflufs: sie scheinen niedrigere Temperaturen vorzuziehen. Der Umstand, dals das Auftreten von Verzweigungen durch bestimmte Eingriffe veranlalst werden kann, deutet darauf hin, dafs die verzweigten Formen an die saprophytische Lebensweise besser, als an die parasitische angepafst sind.

Die Frage, ob es sich in all diesen Fällen um eine echte Myzelbildung im Sinne der Pilze oder um sogenannte falsche Verzweigung handelt, ist für die systematische Stellung gleichfalls von grofser Wichtigkeit. Diese Frage wurde von verschiedenen Autoren behandelt; die meisten haben sich für echte Verzweigung ausgesprochen. Andauernde genaue Beobachtung eines sich entwickelnden Fadens lehrt zweifellos, dafs es sich hier um eine echte Myzelbildung handelt. Sowie der Faden eine gewisse Länge erreicht hat, erfolgt die Zweigbildung. Diejenige Stelle des Fadens, wo die $\mathrm{Z}_{w}$ eiganlage eintritt, dokumentiert sich als eine höckerförmige, körnchenartige, lichtbrechende Erhabenheit. Diese wächst gleichfalls fadenförmig in der zu dem Hauptfaden senkrechten Richtung. Die Verzweigungen entstehen in der Kontinuität des Fadens. Sie sind in der Regel kürzer als jener.

\section{Fortpflanzungserseheinungen.}

Bei der Untersuchung von jungem Material in hängendem Tropfen oder im gefärbten Präparate scheinen die Stäbchen oder Fäden aus Protoplasmainhalt und deutlich differenzierter Membran zu bestehen. Etwas ältere Objekte zeigen ein anderes Verhalten. Der Protoplasma- 
inhalt ist kein homogenes, gleichmälsig gefärbtes Gebilde mehr. Er scheint in einzelne intensiv tingierte Stücke zu zerfallen, die voneinander durch farblose Unterbrechungen getrennt sind. Die gefärbten Teile sind ungleich grofs, dementsprechend sind auch die Unterbrechungen von verschiedener Ausdehnung. Die Teilstücke scheinen von den farblosen Stellen durch keine Querwände getrennt zu sein. Das alles macht den Eindruck, als wie wenn das Protoplasma sich im Innern des Stäbchens oder Fadens an einigen Stellen kontrahiert, zusammengeballt hätte; um das so konzentriertere Protoplasmaklümpchen herum mülsten notwendigerweise leere oder infolge der Kompression des Protoplasmas mit Saft gefüllte Partieen entstehen.

\section{Fragmentation.}

Wie bereits früher erwähnt, habe ich wiederholt festgestellt, dafs Protoplasmastücke sich um die "Körnchen" zusammenballtèn. Der Vorgang läfst sich im hängenden Tropfen ebenfalls beobachten. Diese Methode hat noch den Vorteil, dafs sie das weitere Schicksal des zerstückelten Fadeninhaltes zu verfolgen erlaubt. Die Versuche wurden an Hand von Korn I, Timotheebazillus und Blindschleichentuberkulosebazillus ausgeführt. Die Objektträger mit hängenden Bouillontropfen wurden ungefähr 14 Tage lang im Brutschrank gelassen und von Zeit zu Zeit mikroskopisch untersucht. Bereits nach Verlauf von 4-5 Tagen sahen mehrere Individuen in der oben beschriebenen Weise aus; am 7. resp. 9. Tage sah man Protoplasmastücke aus dem Faden austreten, ihre Form etwas abrunden und in Stäbchen oder Fäden auswachsen. Dieser Vorgang ist von den Bakteriologen hauptsächlich für die Aktinomyzeten angegeben und als Fragmentation bezeichnet worden; die keimungsfähigen Protoplasmastücke werden Fragmentationssporen genannt. Einige Autoren verwechseln die Fragmentation nicht selten mit der Sporenbildung; manchmal wird sie als von der Oidienbildung und Segmentation der Aktinomyzeten nicht wesentlich verschieden beschrieben. Diese Begriffe sind scharf auseinander zu halten. Während die echten Sporen sich innerhalb der Muttermembran mit einer eigenen Membran umkleiden, die sie widerstandsfähiger als die übrigen vegetativen Teile macht, zeigen die Fragmentationssporen ein anderes Verhalten. Ihre Widerstandsfähigkeit scheint derjenigen der nicht fragmentierten Formen gleich zu sein. Was wiederum die Segmentation betrifft, so unterscheidet sich diese von der Fragmentation wesentlich dadurch, dafs hier die Membran des Fadens, die ja bei der Fragmentation passiv bleibt, mitwirkt. 
Die Botanik kennt den Ausdruck Fragmentationsspore nicht. Der Vorgang der Fragmentation kann demjenigen der Aplanosporenbildung an die Seite gestellt werden. Dafs die Fragmentationssporen keine Involutionsformen sind, und weiter, dafs die Fragmentation durchaus als ein vitaler Vorgang aufgefafst werden'muls, beweist die Tatsache, dals sie bei jungen, der weiteren intensiven Entwicklung fähigen Kulturen stattfindet. In ganz jungen Kulturen ziehen die Mikroorganismen einen anderen Vermehrungsmodus - die Zweiteilung vor. Die Fragmentation tritt somit auf einem späteren Entwicklungsstadium der Mikroorganismen auf und zwar hauptsächlich nur unter bestimmten Bedingungen. Sie tritt bei Temperaturen, die unterhalb des Temperaturoptimums liegen, früher und häufiger als bei Temperaturoptimum und höher auf. Bei den Formen, die ich in dieser Hinsicht untersucht habe (Pseudotuberkulosebazillus Petri, Mistbazillus, Korn I, Geflügeltuberkulosebazillus, Timotheebazillus) war für die Fragmentation die Temperatur von $28^{\circ} \mathrm{C}$. am günstigsten. Die fragmentierten Formen findet man am häufigsten in den schon zum Teil eingetrockneten Partieen der Kultur. Der Nährboden bleibt gleichfalls nicht ohne Einflufs: besonders günstig waren Serum, Glyzerinagar, Mohrrüben.

Die Fragmentationssporen sind ein Mittel, das die Mikroorganismen im Sinne der echten Sporen, um die Art zu erhalten, in Anwendung bringen. Jedenfalls sind diese Gebilde wegen ihrer viel schwächeren Widerstandsfähigkeit weniger vollkommen, als die echten Sporen. Die Fragmentationssporen kann man deshalb nicht für Dauerformen im Sinne der Bakteriosporen halten.

Die Frage, ob die „Säurefesten ${ }^{\text {, }}$, vor allem die Tuberkelbazillen, Dauerformen besitzen, ist von zahlreichen Forschern behandelt worden. In den meisten Fällen haben die Untersuchungen ein negatives Resultat gezeitigt. Als erster hat sich Robert Koch in seiner Arbeit über die „Aetiologie der Tuberkulose" für die Existenz von Sporen ausgesprochen. Auch andere Autoren, wie Nocard, Metschnikoff, Babes, Czaplewski, haben die Tuberkelbazillen für sporenbildend erklärt. Sie halten die sich intensiver färbenden und schwer entfärbenden Körner oder Teile des Tuberkelbazilleninhaltes für richtige Sporen. Die tinktoriellen Eigenschaften allein genügen nicht um die Sporennatur eines Gebildes zu erkennen. Wesentlich ist auch der Vorgang der Bildung von Dauersporen, der ja bei den Säurefesten mit der eigentlichen Sporenbildung, wie bereits erwähnt, wenig zu tun hat. 
Aufser den fragmentierten Formen gibt es bei jungen Kulturen hie und da noch anders ausgebildete Individuen, die in älteren Kulturen überwiegen. Das sind die längst bekannten Kolben-und Keulenformen. Charakteristisch sind die letzteren. Die Keulen färben sich schr intensiv, sind rund, scharf umrissen und sitzen einem Ende des Stäbchens wie ein Stecknadelknopf auf. Besonders interessant ist es, dafs man die Keulen häufig im hängenden Tropfen, wie in den gefärbten Präparaten von den Stäbchen losgelöst findet. Trotz wiederholter Bemühungen konnte ich das weitere Schicksal dieser Gebilde nicht verfolgen, - ein Auskeimen habe ich nicht gesehen. Dafs dies möglich ist, ist ohne weiteres zuzugeben, um so mehr, als man in den Präparaten, die den zuletzt erwähnten zeitlich folgten, häufig ganz jungen kurzen Stäbchen ohne Keule begegnet, die man vielleicht für Auskeimungsprodukte ansehen kann. Anders als eine Art Dauerform kann man die Kolben und Keulen schwerlich deuten. Ein Durchmustern zahlreicher Präparate verschieden alten Materials erweckt den Eindruck, als wären die Keulen ein weiteres Entwicklungsstadium der Kolben. Das Entstehen kugeliger Gebilde am Ende des Stäbchens und ihr Loslösen von demselben erinnert an den in der Mykologie bekannten Vorgang der Konidienbildung. E. Levy gibt in seiner Arbeit „Zur Morphologie und Biologie der Tuberkelbazillen" an, dals "man in 2-4 Monate alten Tuberkelbazillenkulturen, die auf Kartoffelnährböden, seltener auf solchen, die auf Glyzerinagar gewachsen waren, Exemplare findet, die nahe dem Stäbchenende, oder an diesem Ende selbst, oder schliefslich bisweilen mehr gegen die Mitte eine besondere Art von kugeligen oder kolbigen Auftreibungen zeigen." Levy identifiziert die letzteren auf Grund der Untersuchungen von Neukirch über die Aktinomyceten mit Oidiensporen. Die Gebilde von $\mathrm{Levy}$, die nur in alten Kulturen vorkommen, -sind höchst wahrscheinlich Involutionsformen. Nach unseren Erfahrungen ist ihre Identität mit Oidiensporen nicht stichhaltig. Schon die Abbildungen Neukirchs machen seine Auffassung sehr unwahrscheinlich; sie sprechen vielmehr für die Ähnlichkeit mit Chlamydosporen.

Nicht selten findet man in Präparaten Stäbchen, die an einem Ende kolbenähnliche Auftreibungen aufweisen. Diese sind zu zweien gegeneinander unter einem stumpfen Winkel geneigt oder in einer Geraden gelagert. Die Auftreibungen liegen stets im Scheitel des Winkels. Im älteren zeitlich darauf folgenden Untersuchungsmaterial waren die Stäbchen so nahe aneinander gerückt, dafs zwischen ihnen ein nur schwer erkennbarer $\mathrm{Z}$ wischenraum übrig blieb. Die kolbigen 
Anschwellungen der beiden Stäbchen waren noch deutlich zu erkennen. Dasselbe Bild habe ich auch in einem Sputumpräparat beobachtet. In noch älteren Präparaten findet man Stäbchen, die etwas länger als die vorher beschriebenen sind und in der Mitte eine kugelige Auftreibung tragen. Aufser diesen Formen kommen andere vor, die aus dem kugelförmigen Mittelstück bestehen, das an zwei diametral liegenden Punkten winzige Anhängsel, wie Stäbchenreste, tragen. Daneben sind noch die von Anhängseln ganz freien Kugeln zu sehen. In den gefärbten Präparaten sind die Kugeln intensiv schwarzrot gefärbt. Diese Formen kommen so oft nebeneinander vor, dafs man ihre Zusammengehörigkeit schwerlich bezweifeln kann. Irgend welche weitere Details habe ich nicht beobachtet. Der zuletzt beschriebene Vorgang erinnert an die Kopulation bei Mucorineen. Dals die beiden Vorgänge irgendwie sachlich zusammenhängen, will ich durch diese Worte keineswegs aussprechen.

Es sei hier noch auf die von einigen Autoren (Spengler, van Niessen) beschriebenen "Splitter" hingewiesen. Diese Splitter sollen ganz kurze vermehrungsfähige Teile des Tuberkelbazillus darstellen und sind z. B. im Sputum und auch in dem Neutuberkulin von $\mathrm{Koch}$ nachgewiesén worden. Dieses Neutuberkulin wird bekanntlich durch mechanische Zerkleinerung von Tuberkelbazillen erhalten. Die Infektiosität dieses nach Koch hergestellten Präparates konnte Thellung (Zentralbl. für Bakt. Bd. 32) nachweisen. Auf Grund unserer Untersuchungen ist die Annahme von Spengler und von van Niessen plausibel: die Splitterstellen Fragmente von Tuberkelbazillen dar.

Wenn wir die Fortpflanzungserscheinungen der „Säurefesten ${ }^{\text {" mit }}$ denjenigen anderer Bakterien vergleichen, so finden wir ganz erhebliche Unterschiede. Der Fortpflanzungsprozels der Säurefesten ist komplizierter und höher differenziert. In dieser Hinsicht liegen bei den Säurefesten die Verhältnisse ähnlich, wie bei den Aktinomyceten. Ein anderer Grund, der für die Verwandtschaft der "Säurefesten“ und der Strahlenpilze spricht, ist das Vorhandensein von Verzweigungen.

Die in diesem Kapitel besprochenen Erscheinungen sind für die Stellung der ${ }_{n}$ Säurefesten ${ }^{*}$ im System von Wichtigkeit.

\section{Abschnitt III. Biologisches.}

Das biologische Verhalten der verschiedenen Stämme zeigt derartige Ähnlichkeit, daf́s die ganze Gruppe gemeinsam behandelt werden kann. 


\section{Zuhehtungstemperatur.}

Wie wir schon bei der Einzelbesprechung gesehen haben, lassen sich die Säurefesten auf verschiedenen Nährböden, sowohl tierischen als auch pflanzlichen, innerhalb weiter Temperaturgrenzen leicht züchten. Die parasitischen Formen weisen infolge ihrer Herkunft engere. Temperaturgrenzen auf.

\section{Nährböden.}

Von den pflanzlichen Nährböden hat sich für die Züchtung die Kartoffel, und zwar die mit 10\% Glyzerinwasser und die nach v. B e hring hergestellten Kartoffeln, als der beste erwiesen. Weniger günstige Resultate hat man mit den $10 \%$ Glyzerinbouillon enthaltenden Kartoffelkeilen erzielt. Die Ursache liegt, wahrscheinlich in einer allzu starken Anhäufung von Peptonen. Die Kartoffelkulturen sind auf verhältnismälsig geringe Änderungen der Nährbodenbeschaffenheit sehr empfindlich. Daher mufs beim Studium der Kartoffelkulturen auf alle in Frage kommenden Verhältnisse besonderes Gewicht gelegt werden. So ist das Verhalten der Kultur je nach dem Wassergehalt der Kartoffel verschieden. Die Differenzen äufsern sich in der Farbstoffbildung, Üppigkeit, unter Umständen sogar in dem Aussehen der Kultur. Die Tuberkelbazillen sind in dieser Beziehung ganz besonders empfindlich. Am besten eignen sich für die Züchtung die saftigen, wasserreichen Kartoffeln. Selbstverständlich müssen bei vergleichenden Untersuchungen nur diejenigen Kartoffelkulturen unmittelbar verglichen werden, für die dieselbe Kartoffelsorte verwendet wurde. Bei Mohrrüben ist das Verhalten ähnlich.

Von den tierischen Nährböden eignen sich für die Züchtung der Säurefesten besonders gut Hirnagar, Serumbouillon (nach v. B e hring), Löff ler'sches Serum, Glyzerinagar, Glyzerinbouillon. Zuckeragar, Zuckerbouillon geben ebenfalls gutes Wachstum. Der H e s s e'sche Nährboden gab wenig befriedigende Resultate. Serum mit Proskau ers Nährsalzen versetzt, trocknet zu schnell aus; es kann deshalb nicht gut für langsam wachsende Kulturen verwendet werden. Für gutes Gedeihen der Kulturen müssen die Nährböden schwach alkalisch oder neutral sein, ein geringer Grad von Acidität wird übrigens gut ertragen. Die Reaktion des Nährbodens bleibt nicht ohne Einflufs auf die Beschaffenheit der Kulturen. So waren die auf alkalischen Kartoffelnährböden gezüchteten Tuberkelbazillenkulturen intensiv mennig-gelb gefärbt, während sie auf dem neutralen Boden grau-weils sind. Im allgemeinen ist die Zusammensetzung, die Reaktion des Nährbodens usw. von so grofsem Einflufs auf das kulturelle wie auf das mikroskopische. Verhalten der säurefesten Mikroorganismen, dals man nur unter Berück- 
sichtigung aller angedeuteten Verhältnisse ein klares Urteil über das Verhalten der Formen gewinnen kann. Auf den verschiedenen Nährböden heben sich verschiedene morphologische und biologische Merkmale der Mikroorganismen in wechselndem Grade hervor. So eignet sich der Kartoffelnährboden am besten, um die Kolben und Keulen zu studieren; die Mohrrüben bei $28^{\circ}$ C. scheinen für die Fragmentation besonders günstig zu sein. Auf Serum sind die Individuen im allgemeinen kürzer, als sonst. Von grofser Wichtigkeit ist auch hier die Züchtungstemperatur. Die Veränderungen, die durch passende Wahl des Nährbodens hervorgebracht werden können, die so grofs sind, dafs sie manchmal zur Aufhebung der typischen Merkmale führen, sind im ersten Teil dieser Arbeit bei den Einzelbesprechungen der Formen hervorgehoben worden.

\section{Farbstoff bildung.}

Im Zusammenhang mit der Züchtungstemperatur und unter Umständen mit dem Alter der Kultur steht die Farbstoff bildung, die bei fast allen Säurefesten stattfindet. Je niedriger die Temperatur, bei der die Züchtung vor sich geht, desto intensiver ist die Farbstoffbildung. Sie kann sogar überhaupt erst bei niedrigeren Temperaturen auftreten. So sind z. B. die Smegmabazillenkulturen bei $37^{\circ} \mathrm{C}$. gewöhnlich farblos, dagegen bei $28^{\circ} \mathrm{C}$, und $22^{\circ} \mathrm{C}$. orange. Dieselben Formen können unter Umständen verschiedene Farbennüancen aufweisen. Die Wahl des Nährbodens ist gleichfalls nicht ganz ohne Einflufs. Die Kartoffelkulturen der Blindschleichentuberkelbazillen sind weifs, während die Hirnagarkulturen stellenweise rosa bis gelbrosa sind. Weitere Bedingung für die Farbstoffbildung ist manchmal ein gewisser Grad der Feuchtigkeit. So z. B. haben die sonst farblosen Hirnagarkulturen von Blindschleichentuberkelbazillen nur in der Nähe des Kondenswassers einige gefärbte Partieen. Im allgemeinen ist die Skala der Farbentöne ziemlich reich; wir treffen hier alle Übergänge von weifs-grau und weifs-gelb zu rötlich, orange und ockergelb.

\section{Aërobes Wachstum.}

Ein bestimmender Faktor im Leben der säurefesten Mikroorganismen ist das Vorhandensein von Sauerstoff. Die negativ ausgefallenen Versuche, sie anaërob zu züchten, lassen sie als obligat aërob bezeichnen.

Die sämtlichen Säurefesten haben zwei charakteristische Eigenschaften gemeinsam: 1. sie besitzen keine Eigenbewegung und 2. sie verflüssigen nicht die Gelatine. 
Sehr übereinstimmend ist weiter das Verhalten aller Säurefesten gegen hohe Temperaturgrade. Um die Widerstandsfähigkeit zu prüfen wurden Bouillonaufschwemmungen von 4-5 Tage alten, sowie vierwöchentlichen Kulturen in sterile Glaspipetten gebracht, die nach der Auffüllung zugeschmolzen wurden. Die Pipetten wurden während einer Stunde im Wasser von bestimmter Temperatur gehalten und dann auf Bouillon und Glyzerinagarröbrchen geimpft. Der zuletzt genannte Nährboden hat sich als günstiger erwiesen; die Resultate, die damit erzielt werden, sind besonders zuverlässig.

Die Ergebnisse der Abtötungsversuche mögen in folgender Tabelle zusammengestellt werden.

Widerstandsfähigkeit der Säurefesten gegen Erhitzung.

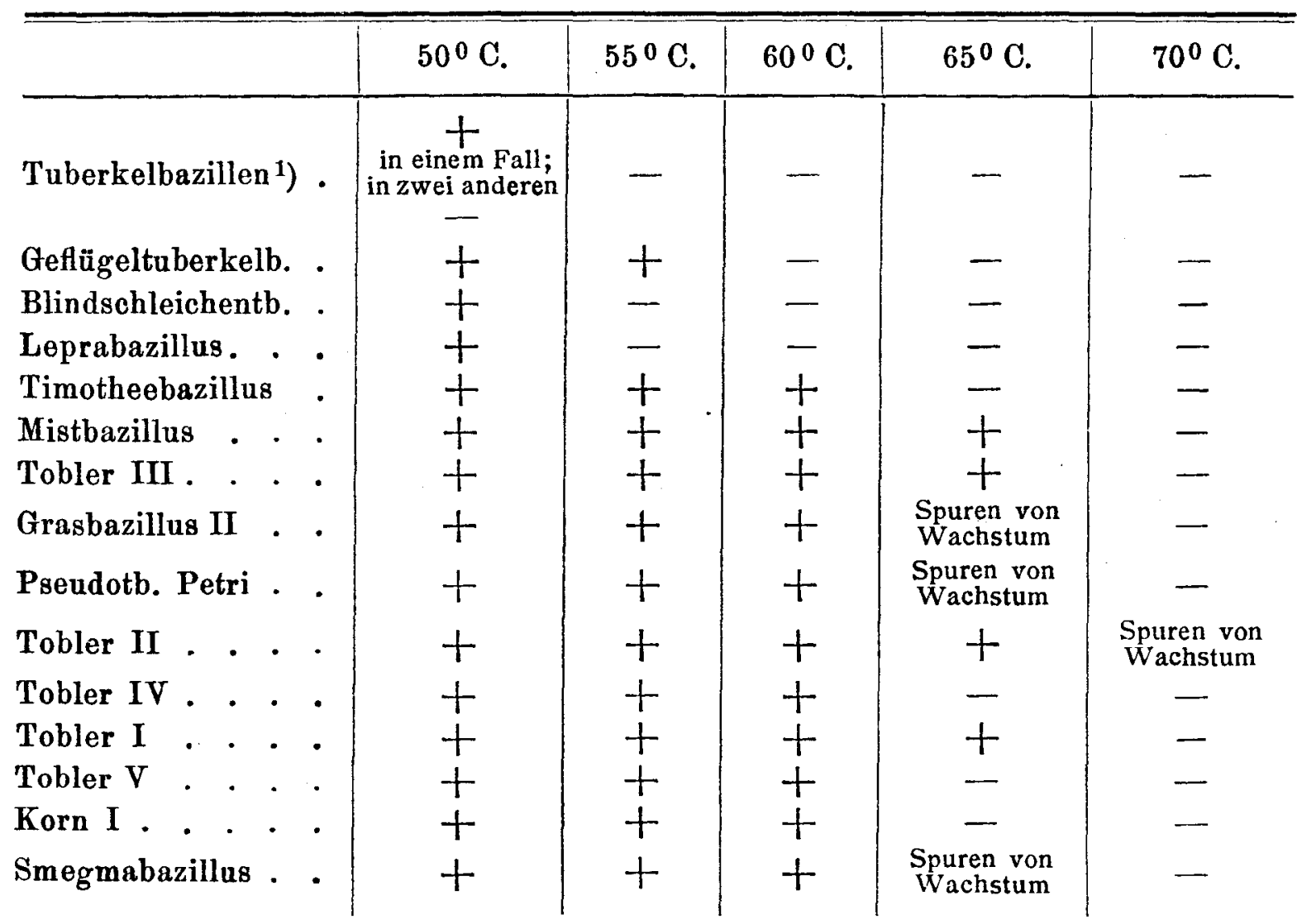

Diese Versuche fielen für junge wie für alte Kulturen im gleichen Sinne aus.

\section{Sãure- resp. Alkalibildung.}

Interessant ist das Verhalten der säurefesten Stämme in bezug auf Säure- oder Alkalibildung. Zum Nachweis der Reaktion wurden als Nährböden Lakmusbouillon, Lakmustraubenzuckerbouillon und Lakmusmilchzuckerbouillon verwendet. Gleich alte Kulturen wurden

1) + bedeutet Wachstum; - Abtötung der Kultur. 
zu gleicher Zeit auf je drei Röhrchen geimpft. Die Bouillonkulturen müssen während längerer Zeit fast jeden Tag kontrolliert werden, weil die Reaktion sehr subtil ist. Es kommt nicht selten vor, dafs sie nach einiger Zeit umschlägt. Da die Reaktionen stark schwanken und nicht gleichförmig verlaufen, so lassen sich die Resultate nicht gut in wenige Worte kleiden. Sie lassen sich am besten in einer Tabelle darstellen. Die Kulturen wurden bei $37^{\circ} \mathrm{C}$. resp. $28^{\circ} \mathrm{C}$. (Blindschleichentb.) aufbewahrt und täglich kontrolliert. Nach zwei Monaten trat eine Veränderung der Reaktion nicht mehr ein.

\section{Sãure- und Alkalibildung in lakmusgefärbter Bouillon, Traubenzueker- bouillon und Milehzuckerbouillon.}

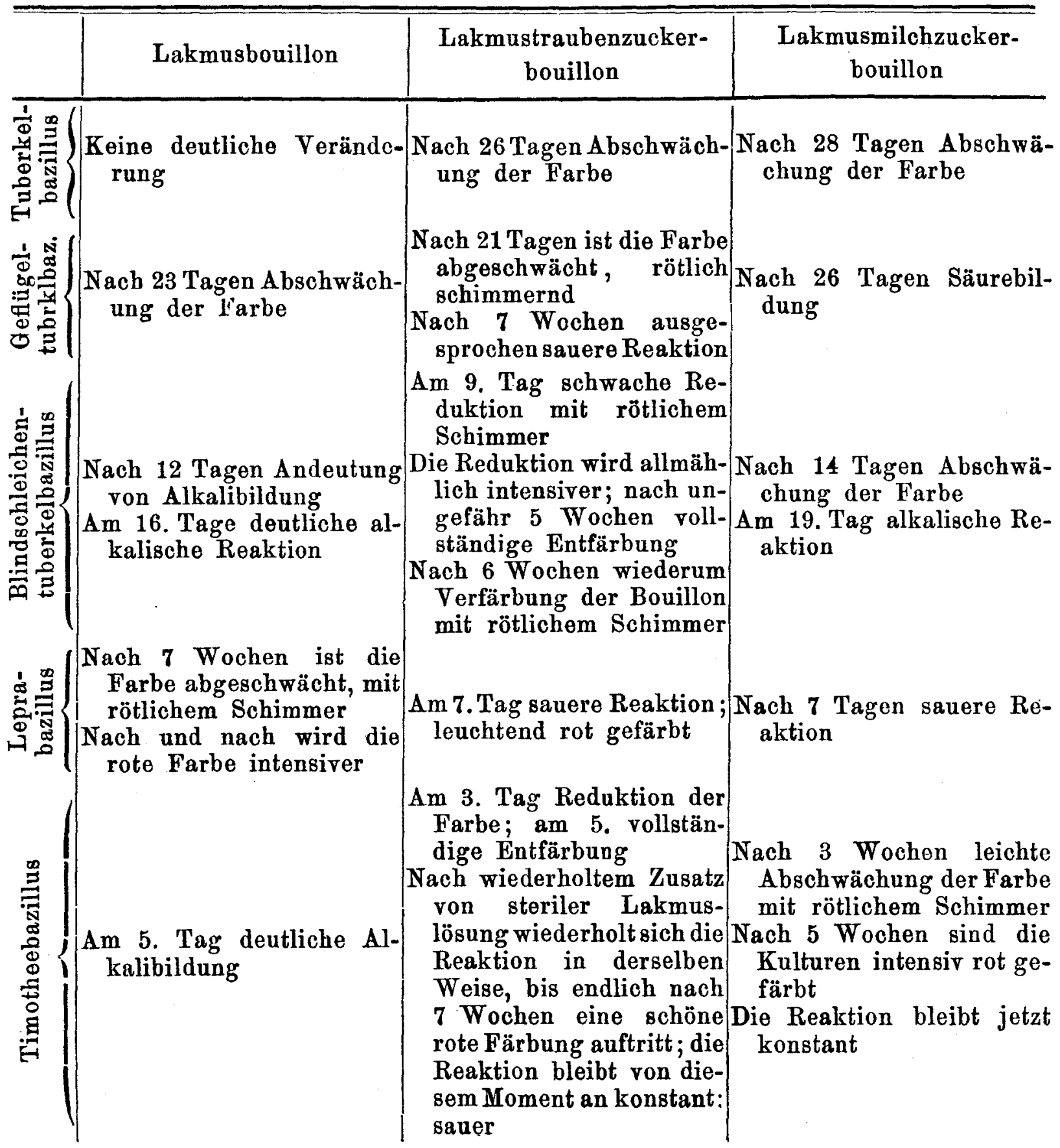




\begin{tabular}{|c|c|c|c|}
\hline & Lakmusbouillon & $\begin{array}{c}\text { Lakmustraubenzucker- } \\
\text { bouillon }\end{array}$ & $\begin{array}{l}\text { Lakmusmilchzucker- } \\
\text { bouillon }\end{array}$ \\
\hline 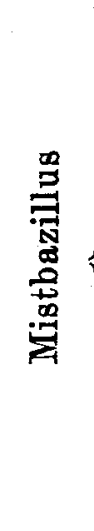 & $\begin{array}{l}\text { Am 9. Tag Andeutung von } \\
\text { Alkalibildung } \\
\text { Nach } 13 \text { Tagen: Alkali- } \\
\text { bildung deutlich } \\
\text { Nach } 7 \text { Wochen schimmern } \\
\text { die Kulturen etwas rötlich }\end{array}$ & $\begin{array}{l}\text { Am 2. Tag vollständige } \\
\text { Entfärbung } \\
\text { Nach Zusatz von steriler } \\
\text { Lakmuslösung wird die } \\
\text { Bouillonkultur tiefrot ge- } \\
\text { färbt; in 14 Tagen darauf } \\
\text { tritt Abschwächung der } \\
\text { Farbe ein; innerhalb } 48 \\
\text { Stunden schlägt die Re- } \\
\text { duktion um, die Bouillon } \\
\text { färbt sich rötlich bis end- } \\
\text { lich ganz rot }\end{array}$ & $\begin{array}{l}\text { Am 9. Tag Andeutung ron } \\
\text { Alkalibildung } \\
\text { Nach 15 Tagen starke Re- } \\
\text { duktion } \\
\text { Nach } 3 \text { Wochen Alkali- } \\
\text { bildung } \\
\text { Nach } 5 \text { Wochen ist die } \\
\text { Kultur intensiv rot ge- } \\
\text { färbt - Säurebildung }\end{array}$ \\
\hline 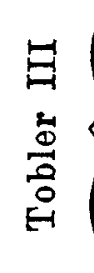 & $\begin{array}{l}\text { Am 3. Tag Abschwächung } \\
\text { der Farbe } \\
\text { Am 13. Tag Andeutung von } \\
\text { alkalischer Reaktion } \\
\text { Nach } 4 \text { Woohen intensiv } \\
\text { rote Färbung }\end{array}$ & $\begin{array}{l}\text { Nach ungefähr } 3 \text { Wochen } \\
\text { sind die Kulturen inten- } \\
\text { siv rot gefärbt }\end{array}$ & $\begin{array}{l}\text { Am 4. Tag Reduktion } \\
\text { Nach 5 Wochen sind die } \\
\text { Kulturen intensiv rot } \\
\text { gefärbt. }\end{array}$ \\
\hline 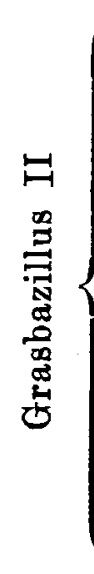 & $\begin{array}{l}\text { Am 9. Tag Andeutung von } \\
\text { Alkalibildung } \\
\text { Nach } 3 \text { Wochen: Alkali- } \\
\text { bildung deutlich } \\
\text { Nach ungefähr } 6 \text { Wochen } \\
\text { sind die Kulturen rot } \\
\text { gefärbt }\end{array}$ & $\begin{array}{l}\text { Am 7. Tag Entfärbung; } \\
\text { nach Zusatz von steriler } \\
\text { Lakmuslösung orfolgt } \\
\text { nochmals Reduktion; am } \\
\text { 18. Tag ist die Bouillon } \\
\text { hellrot gefärbt } \\
\text { Die Reaktion weist wieder- } \\
\text { holt dieselben Schwank- } \\
\text { ungen auf } \\
\text { Nach } 7 \text { Wochen färbt sich } \\
\text { die Bouillon dunkel vio- } \\
\text { lett; die Reaktion bleibt } \\
\text { konstant }\end{array}$ & $\begin{array}{l}\text { Nach } 3 \text { Wochen sind die } \\
\text { Kulturen intensiv dunkel- } \\
\text { rot gefärbt } \\
\text { Nach } 7 \text { Wochen rotriolett }\end{array}$ \\
\hline 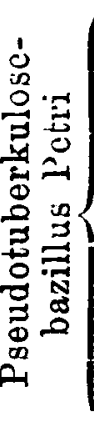 & $\begin{array}{l}\text { Am } 3 \text { Tage Abschwächung } \\
\text { der Farbe; Andeutung } \\
\text { von Alkalibildung } \\
\text { Nach } 3 \text { Wochen alkalische } \\
\text { Reaktion } \\
\text { Nach und nach schlägt die } \\
\text { Reaktion um, nach un- } \\
\text { gefähr } 7 \text { Wochen ist die } \\
\text { Bouillon schmutzig rot } \\
\text { gefärbt }\end{array}$ & $\begin{array}{l}\text { Am 3. Tag Entfärbung } \\
\text { Nach Zusatz von steriler } \\
\text { Lakmuslösung färbt sich } \\
\text { die Bouillon nach unge- } \\
\text { fähr 3 Wochen intensiv } \\
\text { rotviolett; die Reaktion } \\
\text { verläuft ähnlich wie bei } \\
\text { Grasbaz. II }\end{array}$ & $\begin{array}{l}\text { Am 3. Tag Abschwächung } \\
\text { der Farbe; Andeutung von } \\
\text { alkalischer Reaktion } \\
\text { Am 9. Tag Alkalibildung } \\
\text { deutlich } \\
\text { Nach } 4 \text { Wochen: Bouillon } \\
\text { rötlich schimmernd } \\
\text { Nach ungefähr 7. Wochen } \\
\text { rot gefärbt }\end{array}$ \\
\hline $\begin{array}{l}\exists \\
\stackrel{2}{0} \\
\frac{0}{0} \\
0 \\
H\end{array}$ & $\begin{array}{l}\text { Am 7. Tag Entfärbung } \\
\text { Nach Zusatz von steriler } \\
\text { Lakmuslösung werden die } \\
\text { Kulturen rot violett } \\
\text { Nach } 3 \text { Wochen tiefrot. }\end{array}$ & $\begin{array}{l}\text { Am 3. Tag Entfärbung } \\
\text { Nach Zusatz von steriler } \\
\text { Lakmuslösung wird die } \\
\text { Bouillon tief rot; es tritt } \\
\text { wiederholt Entfärbung } \\
\text { resp. Abschwächung der } \\
\text { Farbe ein; nach 3 Wochen } \\
\text { sind die Kulturen rot ge- } \\
\text { färbt; die Reaktion bleibt } \\
\text { konstant }\end{array}$ & $\begin{array}{l}\text { Am 7. Tag Entfärbung } \\
\text { Nach Zusatz von steriler } \\
\text { Lakmuslösung werden die } \\
\text { Kulturen rotviolett } \\
\text { Nach } 3 \text { Wochen - tiefrot }\end{array}$ \\
\hline
\end{tabular}




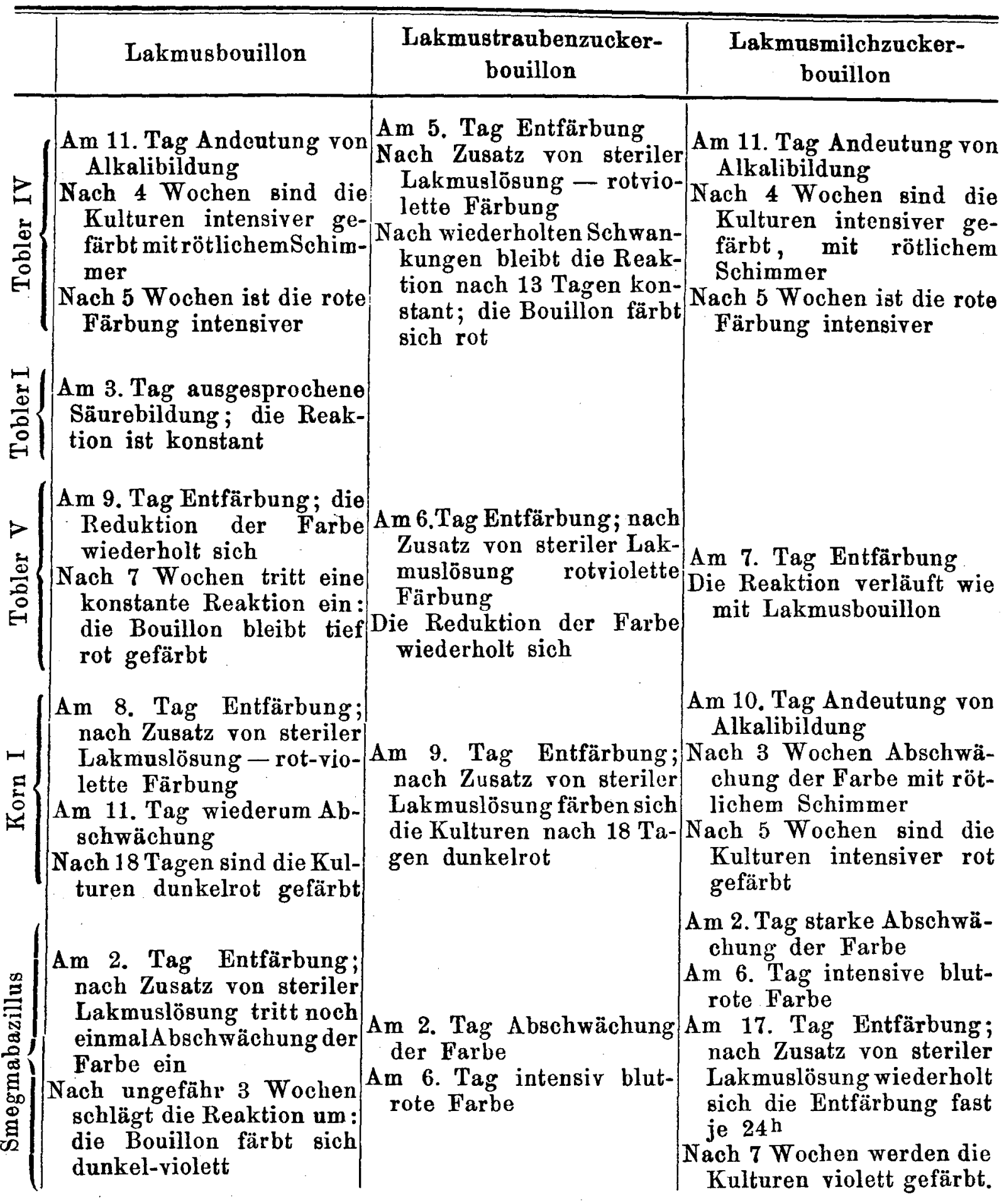

Aus der vorstehenden Tabelle ist ersichtlich, dafs einige Kulturen, wie z. B. Tobler I, Smegmabazillus u. a., ausge sprochene Säurebildner sind. Andere verbalten sich je nach dem Nährboden verschieden. So z. B. gibt bei dem Timotheebazillus die Lakmusbouillon alkalische, die Lakmustraubenzuckerbouillon sauere Reaktion. Interessant war es zu prüfen, wie die verschiedenen Mikroorganismen auf eine Beimengung von Neutralrot reagieren, ob sie auch hier imstande sind den Farbstoff zu reduzieren. Für diese Untersuchung wurden zweierlei Nährböden verwendet: 
Neutralrotzuckeragar und Neutralrotgelatine (Heller). Bei Neutralrotgelatine traten die Reaktionen früher und deutlicher als bei Neutralrotzuckeragar zum Vorschein. Der Übersichtlichkeit wegen mögen die mit Neutralrotgelatine erzielten Resultate in einer kleinen Tabelle zusammengestellt werden. Die Neutralrotgelatinekulturen wurden am 1./II. angelegt.

Reduktion von Neutralrotgelatine.

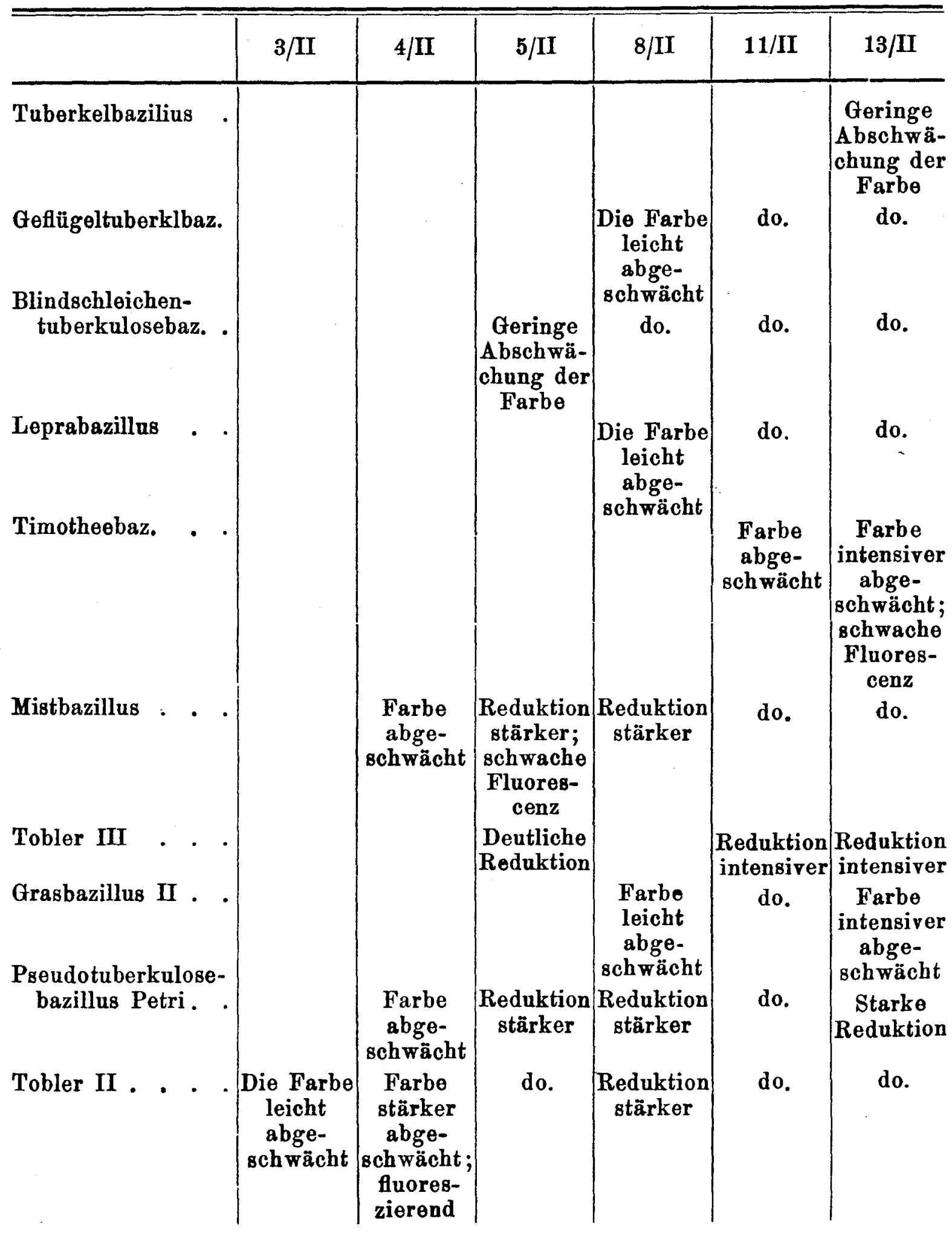




\begin{tabular}{|c|c|c|c|c|c|c|c|c|}
\hline & & & 3/II & $4 / I I$ & $5 / \mathrm{II}$ & $8 / \mathrm{II}$ & $11 / I I$ & $13 / \pi$ \\
\hline Tobler IV & & - & & & $\begin{array}{c}\text { Farbe } \\
\text { leicht } \\
\text { abge- } \\
\text { schwächt }\end{array}$ & $\begin{array}{l}\text { Stärkere } \\
\text { Abschwä- } \\
\text { chung; } \\
\text { schwache } \\
\text { Fluores- } \\
\text { cenz }\end{array}$ & 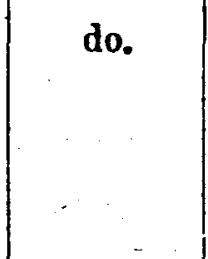 & $\begin{array}{l}\text { do. } \\
\therefore \\
\cdots\end{array}$ \\
\hline Tobler I & $\cdot$ & . & & $\begin{array}{c}\text { Farbe } \\
\text { abge- } \\
\text { schwächt }\end{array}$ & do. & do. & $\begin{array}{c}\text { Farbe } \\
\text { intensiver } \\
\text { abge- } \\
\text { schwächt, } \\
\text { schwache } \\
\text { Fluores- } \\
\text { cenz }\end{array}$ & $\therefore$ \\
\hline Tobler V & • & - & & & & $\begin{array}{c}\text { Farbe } \\
\text { abge- } \\
\text { schwächt }\end{array}$ & do. & $\begin{array}{c}\text { Farbe } \\
\text { intensiver } \\
\text { abge- } \\
\text { schwächt; } \\
\text { Fluores- } \\
\text { cenz }\end{array}$ \\
\hline Korn I . & • & . & & & $\begin{array}{c}\text { Farbe } \\
\text { abge- } \\
\text { schwächt }\end{array}$ & do. & $\begin{array}{c}\text { Intensive } \\
\text { Abschwä- } \\
\text { chung der } \\
\text { Farbe }\end{array}$ & $\begin{array}{c}\text { Starke } \\
\text { Reduktion }\end{array}$ \\
\hline Smegmaba & illus & & $\begin{array}{c}\text { Farbe } \\
\text { abge- } \\
\text { schwächt; } \\
\text { fluores- } \\
\text { zierend }\end{array}$ & $\begin{array}{c}\text { Farbe } \\
\text { stärker } \\
\text { abge- } \\
\text { schwächt }\end{array}$ & $\begin{array}{c}\text { Intensiver } \\
\text { reduziert }\end{array}$ & $\begin{array}{l}\text { Vollstän- } \\
\text { dige Re- } \\
\text { duktion; } \\
\text { goldgelbe } \\
\text { Färbung }\end{array}$ & do. & do. \\
\hline
\end{tabular}

Ordnet man die Mikroorganismen nach ihrem Reduktionsvermögen, so erbält man folgende Tabelle:

Smegmabazillus, Pseudotb. Petri, Mistbazillus, ToblerII, ToblerIII, Tobler V, Korn I, Timotheebazillus, Tobler IV, Tobler I, Grasbazillus II, Lepra, Blindschleichentbbazillus, Geflügeltbbazillus, Tuberkelbazillus.

Nicht in allen Fällen verläuft die Reaktion derjenigen in Lakmusbouillon analog. Bei Smegmabazillus ist eine gewisse Übereinstimmung zu bemerken. Bei allen Kulturen auf Neutralrotzuckeragar war die Reaktion schwächer ausgesprochen, bei einigen Stämmen sogar kaum wahrnehmbar. Nur bei Smegmabazillus war sie ebenso intensiv wie auf Gelatine. Nach ungefähr drei Wochen schlug die Reaktion um: die Kultur färbte sich, von der Oberfläche ausgehend, wieder rötlich, ein Verhalten, das demjenigen des Diphtheriebazillus entspricht.

\section{Abschnitt IV. Systematisches.}

Nachdem wir die säurefesten Mikroorganismen einzeln und im Zusammenhang behandelt haben, gehen wir jetzt dazu über, sie von 
dem pflanzensystematischen Standpunkte aus zu betrachten. Zweifellos bilden die "Säurefesten" eine Gruppe, da sie eine Reihe charakteristischer Merkmale gemein haben. Diese sind: Fortpflanzungserscheinungen, mikroskopischer Bau, Fehlen der Eigenbewegung, Form des Wachstums, Nichtverflüssigen der Gelatine usw. Welcher Platz ist dieser Gruppe im System der Pflanzen zuzuweisen?

Nachdem im Laufe der letzten Jahre zunächst bei den Tuberkułoseerregern die Verzweigungen festgestellt worden sind, meinten zahlreiche Forscher die betreffenden Formen aus dem Reiche der Spaltpilze entfernen zu müssen, um sie dem System an einer anderen Stelle einzureihen. Im Laufe der Zeit sind alle möglichen Ansichten über die Stellung der säurefesten ausgesprochen worden und demgemäls für die ganze Gruppe die verschiedensten Benennungen vorgeschlagen. Metschnik off fafste den Tuberkuloseerreger als ein besonderes Stadium in dem Entwicklungskreise einer Fadenbakterie auf. Diese soll nach ihm die Fähigkeit haben, durch Knospung auszuwachsen, wodurch verzweigte Bildungen zustande kämen. Als Sporen sieht Metschnik off die kleinen rundlichen Körper an, die sich stärker als der Rest des Zellinhaltes färben. Metschnik off schlägt für die Tuberkelbazillen den Namen "Sklerothrix Kochii“ vor.

$\mathrm{Kle}$ in meint, dafs der Tuberkuloseerreger nur eine Phase im Entwicklungsgang eines Mikrobions, welches den Mycelpilzen morphologisch verwandt ist, darstellt. $\mathrm{Kral}, \mathrm{Dubard}$ und einige andere Forscher gliedern die Tuberkuloseerreger samt den Aktinomyceten den Fadenpilzen ein.

Die letztere Ansicht gewinnt an Wahrscheinlichkeit, je näher und eingehender man die säurefesten Mikroorganismen untersucht. Die Säurefesten konnte man nur so lange für Bakterien halten, als man ihre charakteristischen Eigenschaften nicht kannte oder noch nicht richtig zu deuten verstand. Für die ältere Auffassung sprachen die Stäbchenform, die Vermehrung durch Zweiteilung, die pathogenen Eigenschaften, die seltenen Verzweigungen. Diese Merkmale, die man als charakteristisch für die Formen hielt, sind nicht die am meisten typischen: sie stellen vielmehr einen Zustand in dem Entwicklungscyklus des an die parasitäre Lebensweise angepafsten Mikroorganismus dar. Die Verzweigungen, die verschiedenen Arten der Fortpflanzung, die verschiedenen Wachstumsformen, die hauptsächlich bei der künstlichen Züchtung hervortreten, bilden den besten Beweis dafür. Die zuletzt erwähnten Merkmale können dazu führen die säurefesten Mikroorganismen in die Abteilung der Pilze und zwar vorläufig in diejenige 
der Hyphomyceten, der Fadenpilze, zu verweisen. Aller Wahrscheinlichkeit nach, wird man die Säurefesten höher einreihen können, wenn nur die Fortpflanzungsformen, auf die in dieser Arbeit aufmerksam gemacht wird, näher untersucht werden.

Eine den Säurefesten im System ähnliche Stellung nimmt die Gruppe der Aktinomyceten ein, die nach den neuesten Untersuchungen ganz zweifellos von den Schizomyceten zu trennen ist. Die Verwandtschaft zwischen den Säurefesten und den Aktinomyceten ist sehr eng. Manche wesentliche Unterschiede der beiden Formen machen es aber unmöglich sie in eine Gruppe zusammenzubringen. So sind die Wachstumsformen der beiden Gruppen durchaus verschieden. Bei sämtlichen Säurefesten lassen sich die Kulturen leicht von der Unterlage abheben, - bei den meisten Aktinomyceten ist dies nicht der Fall, da dieselben Ausläufer bilden, die in den Nährboden eindringen und sich mit ihm verankern. Was die morphologischen Merkmale anbetrifft, so weichen die Fortpflanzungsformen ebenfalls von einander ab: die Segmentation, die für die Aktinomyceten angegeben wird, konnte ich bei den Säurefesten nicht feststellen. Ein abschliefsendes Urteil möchte ich mir nicht erlauben. Es bleibt weiteren Untersuchungen vorbehalten, dieses Verhalten noch eingehender zu erläutern.

Verzweigungen kommen bei beiden Formen vor; das ist einer der Hauptgründe, weshalb man die beiden Formen für verwandt hielt. ${ }^{1}$ )

Andererseits lassen sich die Säurefesten an eine andere Gruppe, nämlich die der Diphterieerreger zwanglos angliedern.

Die Bakteriennatur dieser Mikroorganismen ist im Laufe der letzten Jahre, nachdem man auch bei ihnen verzweigte Formen gefunden hatte, vielfach bestritten worden. Als Verbindungsglied zwischen den Diphteriebazillen und den Säurefesten ist der Smegmabazillus anzusehen.

Wenn wir die gegenseitigen Beziehungen der Säurefesten eingehender untersuchen, so müssen wir die Frage über die Aufstellung von Arten und Varietäten in folgender Weise beantworten. Wir können bei den Säurefesten von echten Arten nicht sprechen, wenn wir hier die in der Botanik und Zoologie leitenden Prinzipien für die Unterscheidung derselben berücksichtigen. Wie in der Einleitung bereits auseinandergesetzt wurde, können für die Annahme verschiedener Arten nur die wesentlichen Merkmale malsgebend sein. Diejenigen Eigenschaften aber, die durch Einwirkung gewisser Eingriffe

1) Was die systematische Stellung der Aktinomyceten anbetrifft, so verweise ich auf die Arbeit ron Herrn Haass: "Zur Kenntnis der Aktinomyceten." 
Schwankungen unterliegen, können hier deshalb nicht in Betracht kommen: solche Eigenschaften sind für Varietäten charakteristisch.

Wie verhalten sich in dieser Beziehung die Säurefesten? Die wesentlichen Merkmale, d. h. in diesem Falle die Fortpflanzungserscheinungen, der mikroskopische Bau, die Wachstumsform, die Beschaffenheit der Kolonieen, Fehlen der Eigenbewegung, Nichtverflüssigen der Gelatine, - das alles ist für sämtliche Säurefeste bei verschiedenen Bedingungen ganz typisch und konstant. Sie weichen voneinander in bezug auf Verzweigungen, Farbstoffbildung, Gröfse der Individuen, Anpassung an bestimmte Temperaturgrade, Säurefestigkeit, - also Merkmale, die, wie wir gesehen haben, in direktem Zusammenhang mit den Kulturbedingungen, mit der saprophytischen resp. parasitischen Lebensweise stehen. Diese morphologischen und biologischen Unterschiede, denen die Säurefesten ausgesetzt sind, lassen nur die Annahme verschiedener Varietäten zu.

Wir haben bis jetzt von der botanischen Einteilung gesprochen. Bekanntlich werden aber für die Klassifikation der krankheitserregenden Mikroorganismen die krankheitserregenden Eigenschaften ebenfalls berücksichtigt. So erklärt es sich, dafs eine Anzahl Mikroorganismen, wie z. B. die Vertreter der Typhus- und Coligruppe, die man streng botanisch auch nur als Varietäten auffassen würde, in der bakteriologischen Literatur als getrennte Arten beschrieben werden. Die Gruppe, die uns beschäftigt, spielt in dieser Beziehung eine äufserst wichtige Rolle: ist der Tuberkelbazillus als derjenige Krankheitserreger zu bezeichnen, welcher die meisten Erkrankungen beim Menschen und beim Rinde hervorruft, und werden heute noch Mikroorganismen, welche wie der menschliche und der Säugetiertuberkelbazillus nur einen Unterschied im Grad der Virulenz zeigen, als verschiedene Typen unterschieden.

Einen Beweis für die grofse Bedeutung der hier aufgeworfenen Frage können wir in den ausführlichen Referaten und Mitteilungen an dem diesjährigen internationalen Tuberkulosekongrefs in Paris erblicken. Die drei Referenten des Themas „Vergleichendes Studium der verschiedenen Tuberkulosearten", Arloing, Kossel und Ravenel, gelangen nicht zu völlig übereinstimmenden Schlufssätzen. Arloing vertritt die Ansicht, dafs sämtliche Tuberkulosebazillen „wie eine Kette" bihden, ,in welche von Zeit zu Zeit gröfsere, sozusagen die von gewissen Bakteriologen angenommenen Typen vorstellende Ringe eingegliedert werden. Diese Ringe aber versehmelzen sich unmerklich mit den vor- und nachstehenden. ... Das Wort 
,Typus ist blofs um kurz das gewöhńliche Vorkommen besonderer Charaktere bei einem Bazillus anzudeuten zu gebrauchen und kann in diesem bestimmten Sinne wohl dienen."

K ossel spricht hingegen von verschiedenen Typen, dem Typus humanus und dem Typus bovinus.

Ravenel anerkennt die zwei Typen, hebt aber wie die zwei anderen Referenten das Vermögen der Bazillen des Typus bovinus in den menschlichen Körper einzudringen hervor.

Der Hühnertuberkulosebazillus wird von A rloing nicht als eine besondere Art, sondern nur als ein dem Geflügelorganismus angepalster Tuberkelbazillus bezeichnet, welcher durch Zwischenstufen mit dem Säugetiertuberkulosebazillus verbunden ist. Kossel erwähnt den Hühnertuberkulosebazillus als einen von den beiden Typen (humanus und bovinus) verschiedenen Tuberkelbazillus.

$\mathrm{Rabinowitsch}$ vertritt einen Standpunkt, der dem unserigen entspricht, indem sie anführt, dafs die Erreger der Säugetier- und Geflügeltuberkulose ${ }_{n}$ als verschiedenen Tierspezies angepafste Varietäten einer Art aufgefafst" werden müssen.

A rloing nimmt an, dals echte Tuberkulose auch bei Kaltblütern besteht, und dafs der Erreger dieser Erkrankung von den Säugetiertuberkelbazillen herkommt. Nach Kossel werden hingegen die Kaltblütertuberkelbazillen als weit verbreitete Saprophyten betrachtet, die nur hinsichtlich der Säurefestigkeit bis zu einem gewissen Grade mit den echten Tuberkelbazillen übereinstimmen, sonst aber nichts mit ihnen zu tun haben.

Die Aufstellung verschiedener „biologischer Arten ${ }^{\alpha}$ hätte eine gewisse Berechtigung vom praktischen Standpunkte aus. Aus dem hier Mitgeteilten ist aber ersichtlich, dafs eine solche Einteilung zurzeit nicht möglich ist, da die Ansichten der einzelnen mafsgebenden Autoren sehr weit auseinander gehen. Wir wollen uns an das weiter oben Gesagte halten und nur die botanischen Merkmale berücksichtigen. Vielleicht wäre die ganze Tuberkulosefrage richtiger behandelt worden, wenn von Anfang an die morphologischen Eigenschaften eingehender berücksichtigt worden wären, und wenn nicht die Virulenz, welche als konstantes Merkmal nicht angesehen werden kann, allzu sehr in den Vordergrund gestellt worden wäre. - Unter Berücksichtigung der bereits angegebenen Gründe wollen wir versuchen die Stellung der Gruppe der Säurefesten im System näher zu definieren. Mit dieser Frage hat man sich insbesondere in der neuesten Zeit vielfach befalst. Verschiedene Benennungen sind geschaffen 
worden, um die wesentlichen Merkmale der Säurefesten und ihre Beziehungen zu anderen Gruppen hervorzuheben. Wiederholt versuchte man die Tuberkelbazillengruppe in eine genetische Beziehung zu den Streptotricheen zu setzen. Die Streptothrix nimmt eine ganz bestimmte Stelle in der Familie der Chlamydobakteriaceen ein, mit denen die Säurefesten wenig zu tun baben. Überhaupt muls der Begriff Streptothrix bei der Ermittelung der Beziehungen der Säurefesten zu anderen Gruppen aufgegeben werden, da er von den meisten Forschern nicht präzise gefafst wird und infolgedessen den Anlafs zu gröfserer Verwirrung auf dem Gebiete der Systematik gibt. Lehmann und Neumann stellen die Säurefesten - Mykobakterium L. et N. den Diphtheriebazillen - Cor y n e bak teriu m L. et N. - am nächsten.

Auf Grund unserer Untersuchungen glauben wir die von Lehmann und Neumann für die Gattung Mykobakterium aufgestellten Merkmale genauer präzisieren zu können.

In der beigegebenen Tabelle sind die wichtigsten Eigenschaften der von uns untersuchten Stämme zusammengestellt.

\section{Mykobakterium L. et $\mathbf{N}$.}

Schlanke, oft etwas gekrümmte Stäbchen, oft mit Neigung zu kolbigen Anschwellungen der Enden; Verzweigungen, besonders bei saprophytischen Kulturen häufig, und zwar schon in jungen Kulturen. Unbeweglich, keine Sporenformen im Sinne der Bakteriosporen, wohl aber Fragmente. Färbung mit den gewöhnlichen Farblösungen verschieden: die einen, besonders die parasitischen Formen, färben sich schwer, die anderen, saprophytischen, leicht. Parallel mit der Schwere der Färbbarkeit geht die Säurefestigkeit einher.

Aussehen der Kulturen: Wachstum der saprophytischen Formen leicht, der parasitischen schwerer. Keine Verflüssigung der Gelatine, kein Festhaften an dem Nährboden. Kulturen meist trocken, deutlich erhaben; unregelmäfsig, warzenförmig oder mit Fältelung Farbstoffbildung bei fast allen. Aërobes Wachstum.

Zum Schlufs sei mir erlaubt, Herrn Privatdozenten Dr. W. S il b e r s ch midt-Zürich für die Anregung zu dieser Arbeit und für die mannigfache wirksame Unterstützung, sowie Herrn Prof. Dr. M. FickerBerlin für das Interesse, mit welchem er die Arbeit verfolgte und für seine vielen nützlichen Ratschläge meinen besten Dank auszusprechen. Ich fühle mich ebenfalls Herrn Professor Dr. H. Schinz-Zürich für den-stets bereitwilligen Rat zum Dank verpflichtet. 


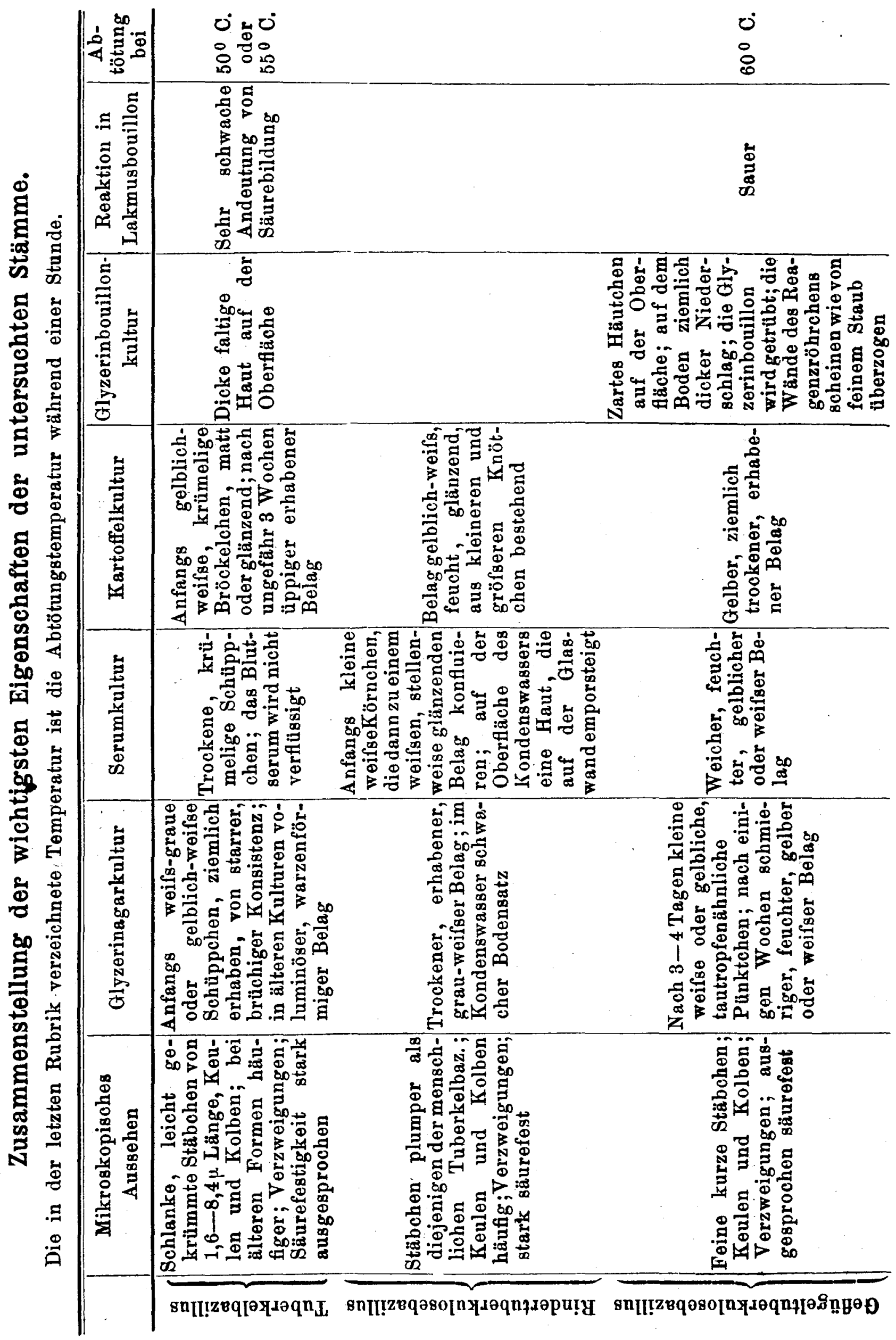




\begin{tabular}{|c|c|c|c|c|}
\hline 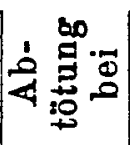 & $\begin{array}{l}0 \\
0 \\
10\end{array}$ & $\begin{array}{l}0 \\
0 \\
10 \\
\text { in }\end{array}$ & $\begin{array}{l}0 \\
0 \\
10 \\
0\end{array}$ & $\begin{array}{l}0 \\
0 \\
0\end{array}$ \\
\hline 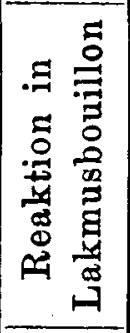 & 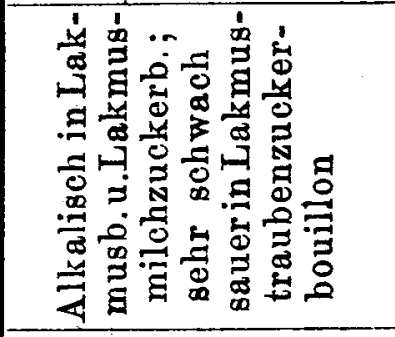 & 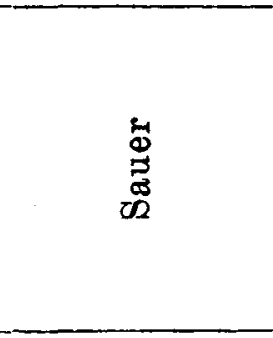 & 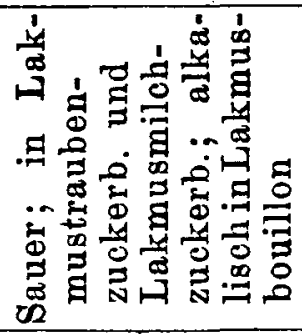 & 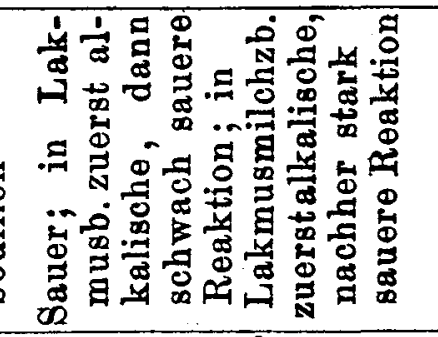 \\
\hline 袁 & . & 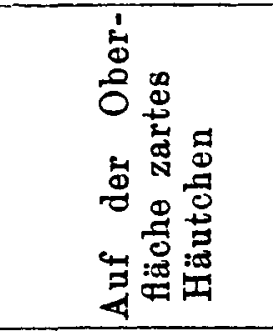 & 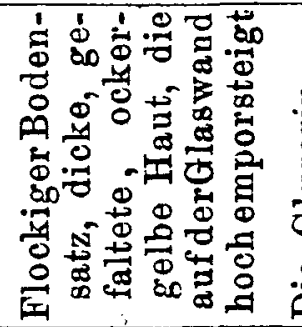 & 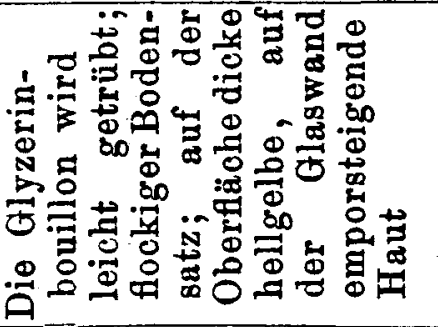 \\
\hline 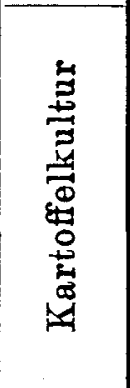 & 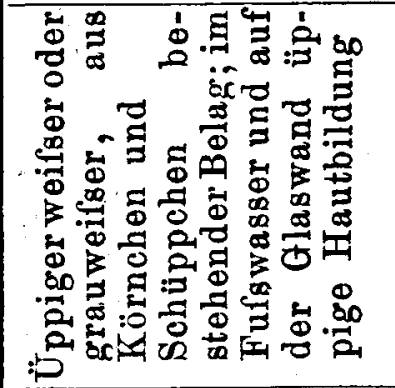 & & 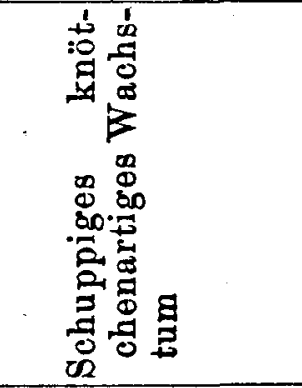 & 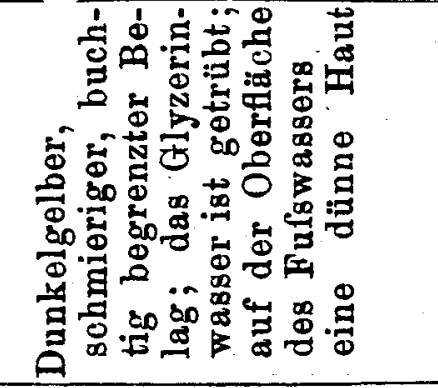 \\
\hline 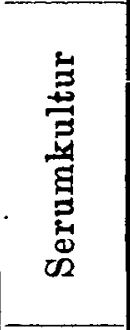 & 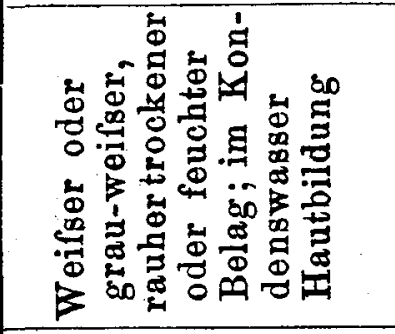 & 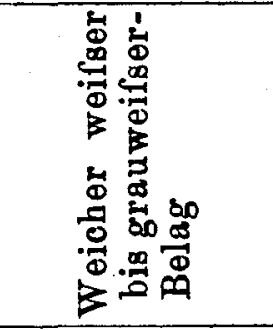 & 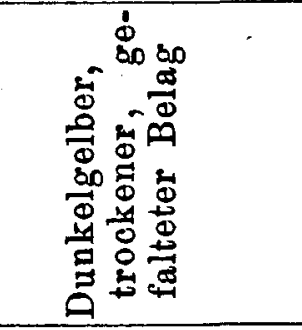 & 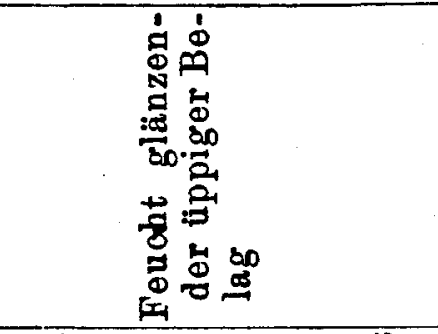 \\
\hline 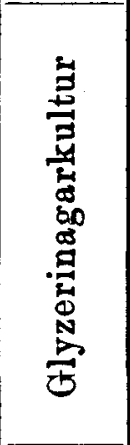 & 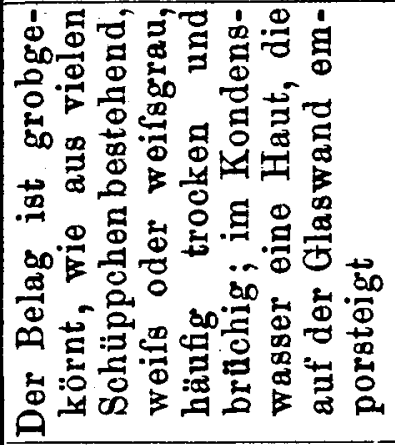 & 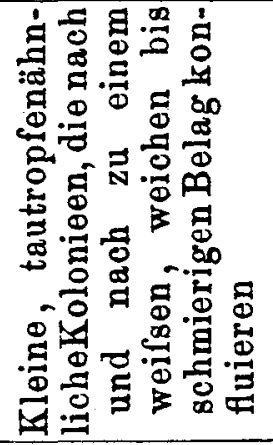 & 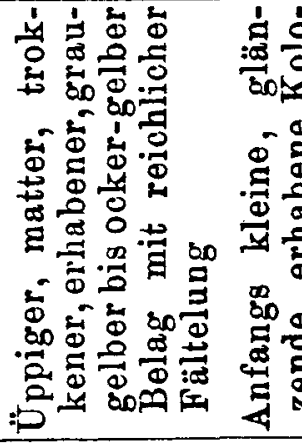 & 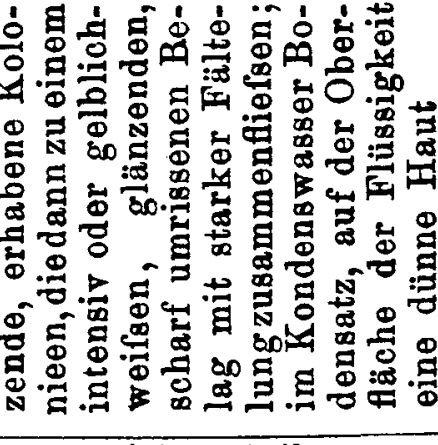 \\
\hline \multirow[t]{2}{*}{ 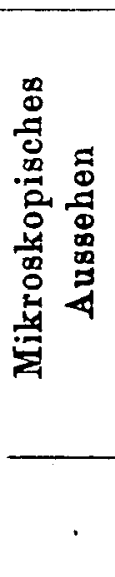 } & 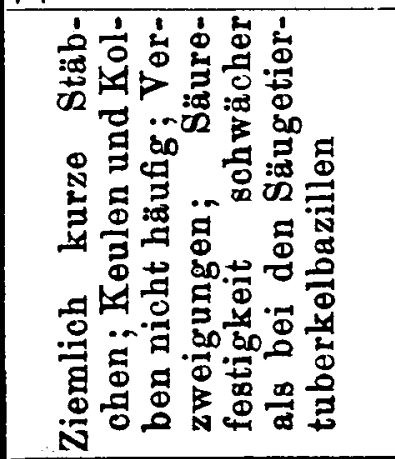 & 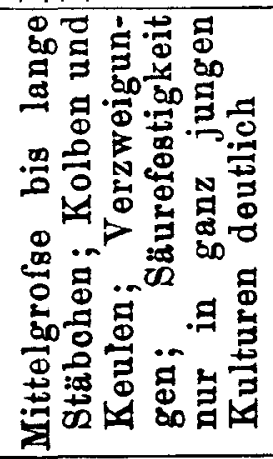 & 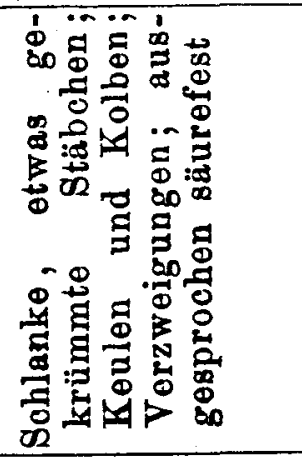 & 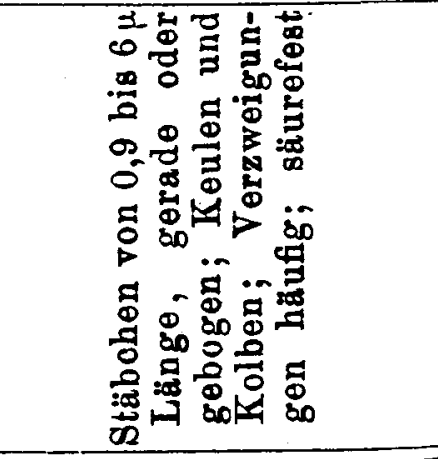 \\
\hline & 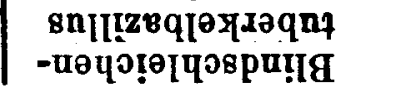 & ${ }^{\theta} \mathbf{T}$ & $\begin{array}{l}\text { snII!Z8q } \\
\text {-әөчๆ0u!! }\end{array}$ & $\mathbf{N}$ \\
\hline
\end{tabular}




\begin{tabular}{|c|c|c|c|c|}
\hline 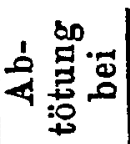 & $\begin{array}{l}0 \\
0 \\
0\end{array}$ & $\begin{array}{l}\dot{0} \\
0 \\
i\end{array}$ & $\begin{array}{l}0 \\
0 \\
\stackrel{0}{0}\end{array}$ & $\begin{array}{l}0 \\
0 \\
0 \\
\mathbb{N}\end{array}$ \\
\hline 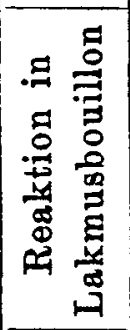 & 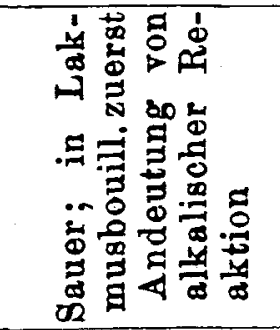 & 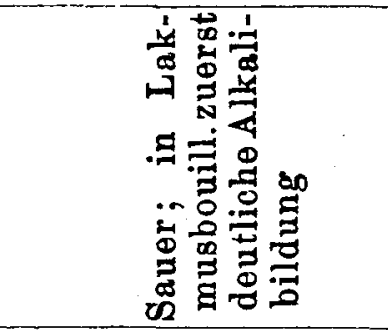 & 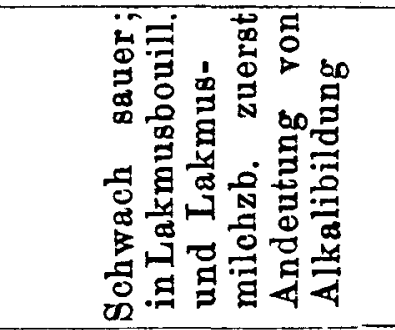 & 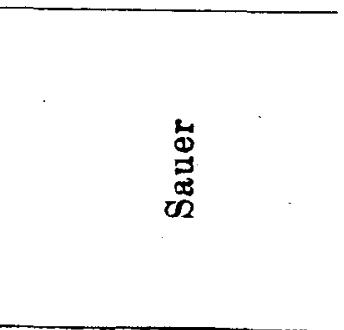 \\
\hline 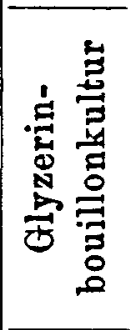 & 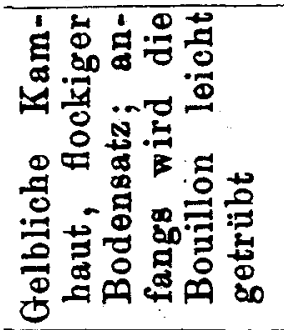 & 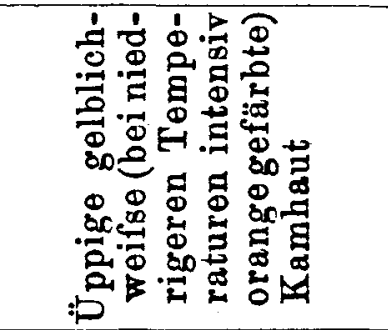 & 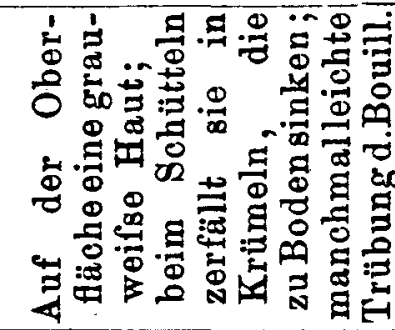 & 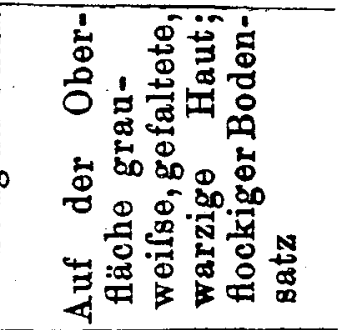 \\
\hline 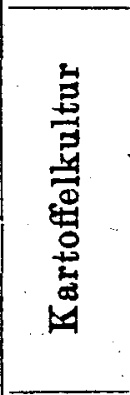 & 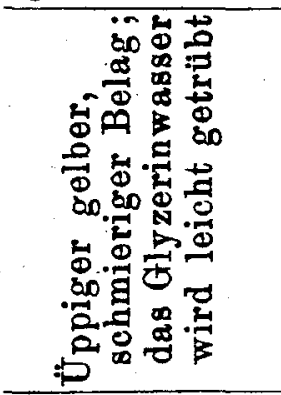 & 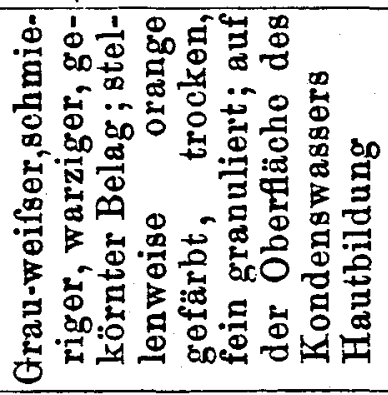 & 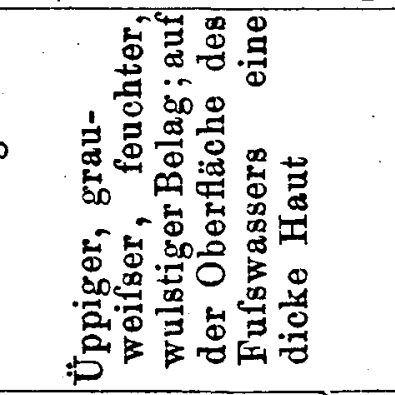 & 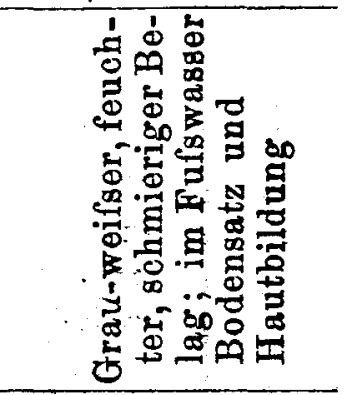 \\
\hline 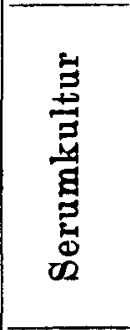 & 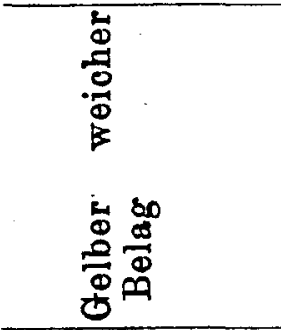 & 告 & 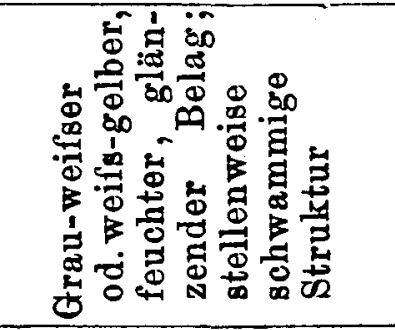 & 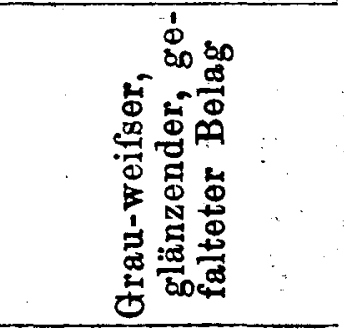 \\
\hline 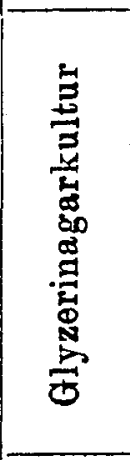 & 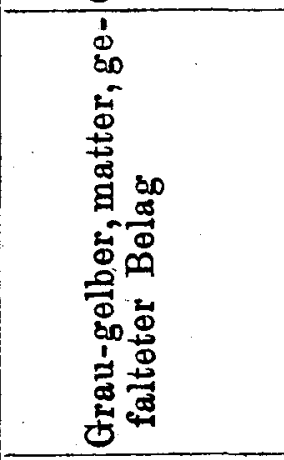 & 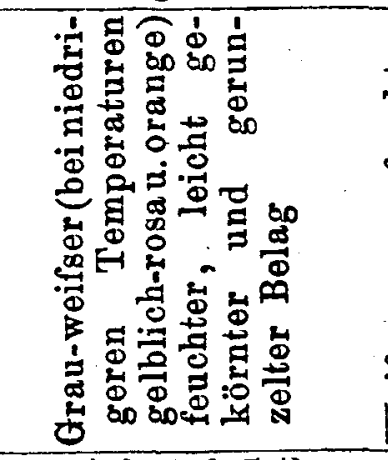 & 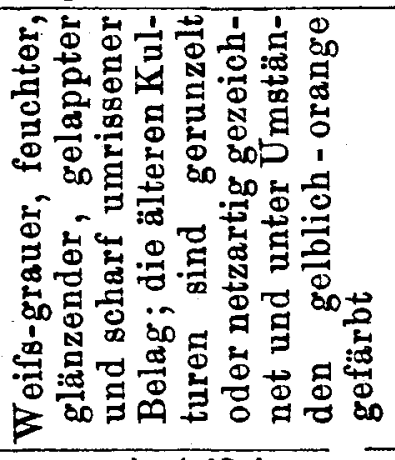 & 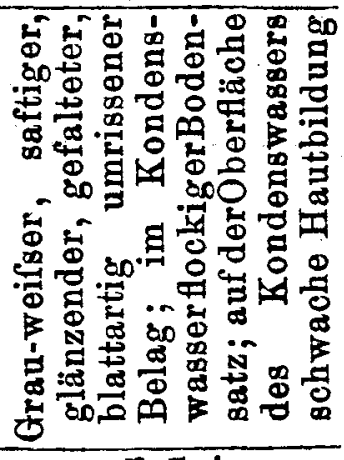 \\
\hline 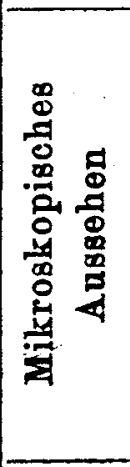 & 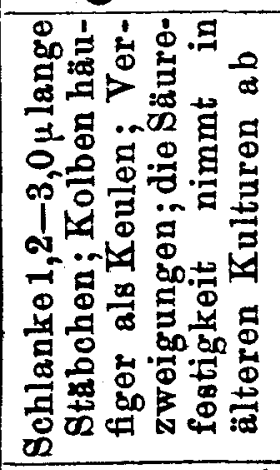 & 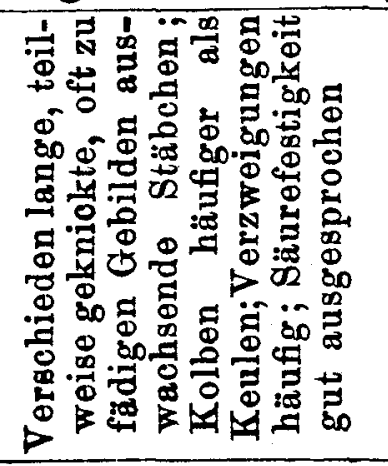 & 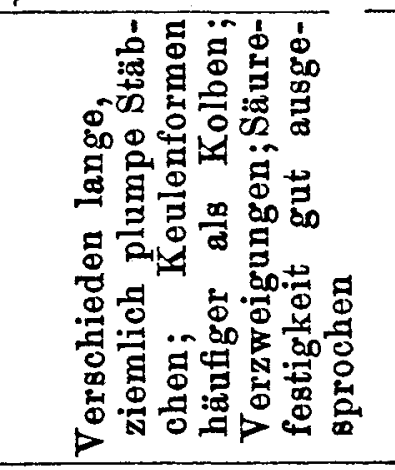 & 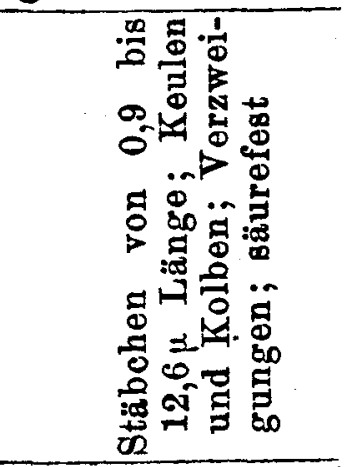 \\
\hline & III & IItzもqsв. & 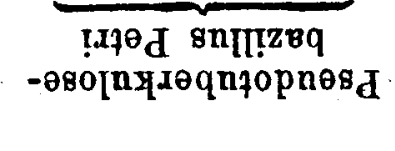 & $\underset{30}{\text { II IO }}$ \\
\hline
\end{tabular}




\begin{tabular}{|c|c|c|c|}
\hline ". & $\begin{array}{l}0 \\
0 \\
8 \\
0\end{array}$ & $\begin{array}{l}0 \\
0 \\
0\end{array}$ & $\begin{array}{l}0 \\
0 \\
18 \\
0\end{array}$ \\
\hline 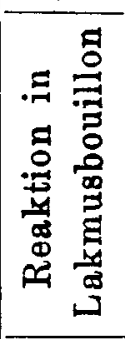 & 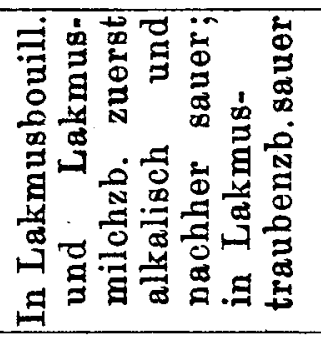 & 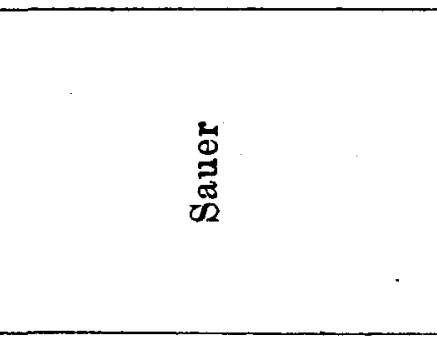 & 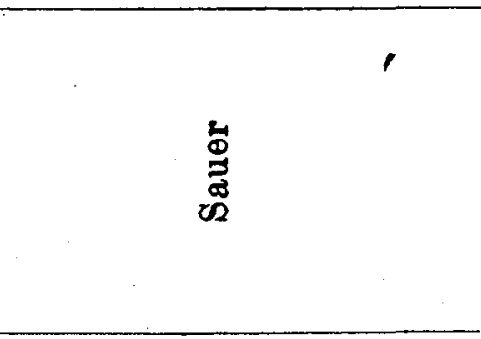 \\
\hline 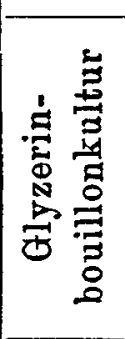 & 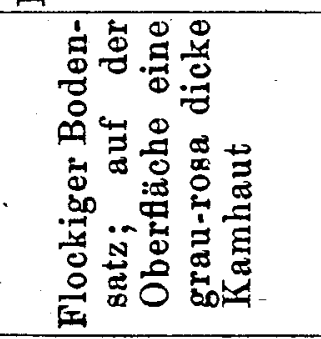 & 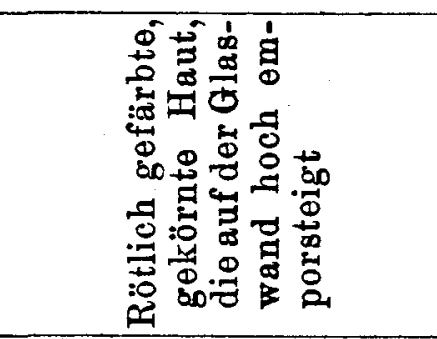 & 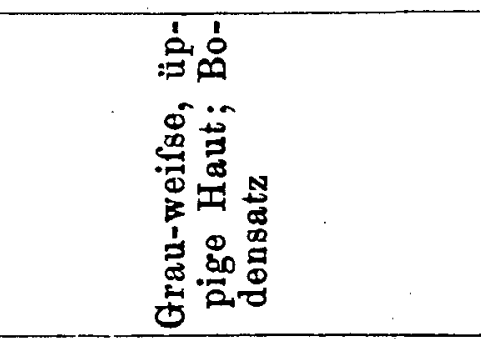 \\
\hline 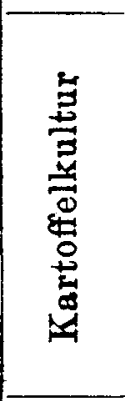 & 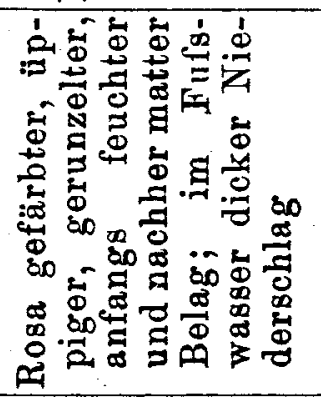 & 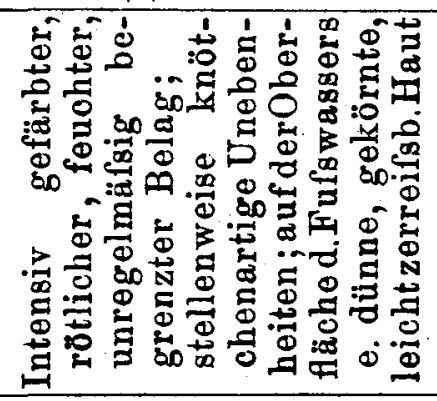 & 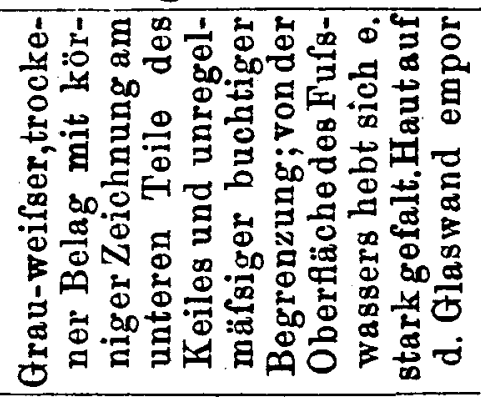 \\
\hline 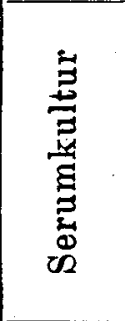 & 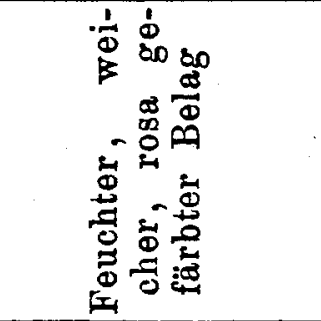 & 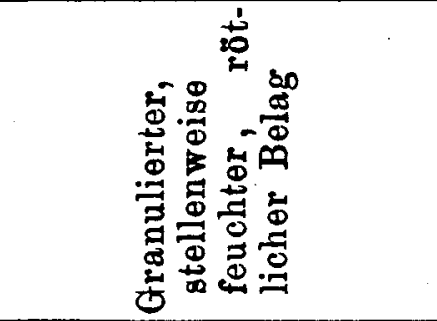 & 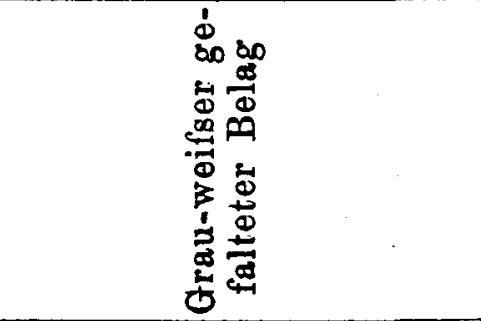 \\
\hline 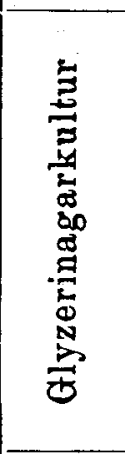 & 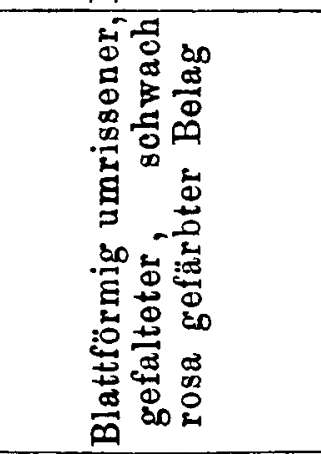 & 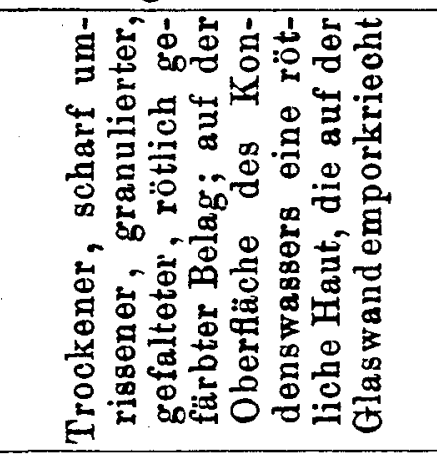 & 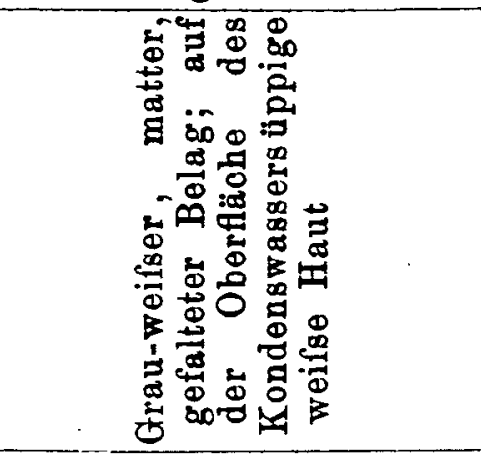 \\
\hline 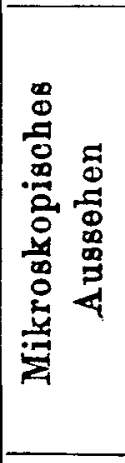 & 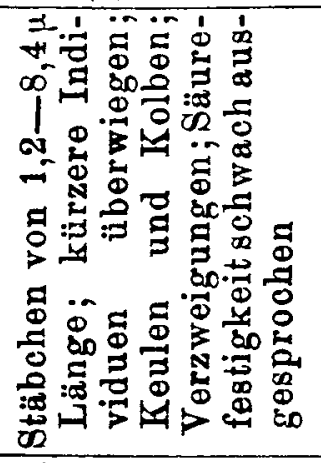 & 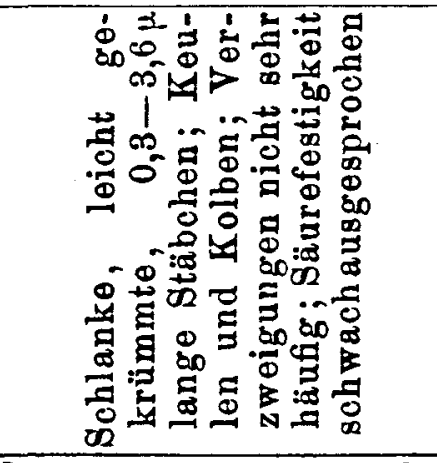 & 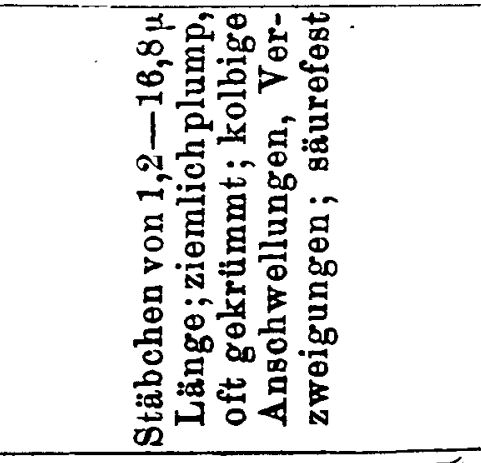 \\
\hline & $\Lambda I$ dә[qoL & I دอІq० $\mathrm{L}$ & $\Lambda x \theta$ \\
\hline
\end{tabular}




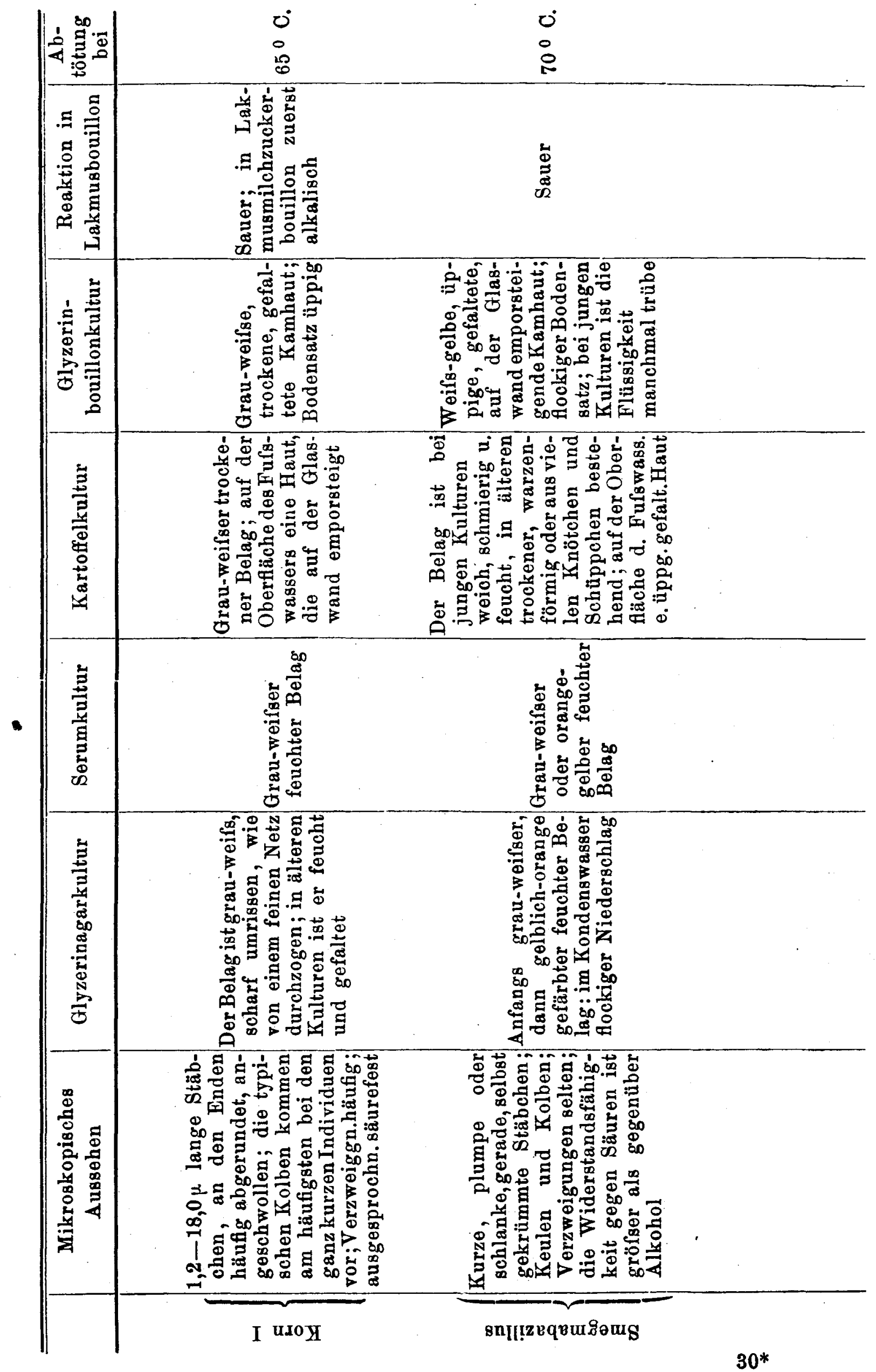




\section{Literatur.}

Almquist E., Untersuchungen über einige Bakteriengattungen mit Mycelien.

Zeitschr. f. Hyg. Bd. VI. 1890.

Arloing, Berichte an dem internationalen Tuberkulose-Kongrefs Paris 1905, pag. 96.

A rons on, Zur Biologie des Tuberkelbazillus. Berlin. klin. Wochenschr. 1898 Nr. 22.

Arrigo et Stampacha, Beitrag zum Studium der Tuberkulose. Ctrbl. f. Bakt.

Bd. XXIII, 1898, pag. 64.

Ascher, Untersuchungen von Butter und Milch auf Tuberkelbazillen. Zeitschr.

f. Hyg. Bd. XXXII, 1898, pag. 329.

Baumgartens Jahresberichte 1885-1901.

v. Behring, Roemer, Rüppel, Tuberkulose. Beiträge zur experiment. Therapie, Heft 5, 1902.

Bernheim und Folger, Über verzweigte Diphtheriebazillen. Ctrbl. für Bakt.

Bd. XX. 1896.

B onh off, Über das Vorkommen von Tuberkelbazillen in der Marburger Butter und Milch. Hyg. Rundschau 1900 pag. 913.

Bordoni-Uffreduzzi, Über die Kultur des Leprabazillus. Ctrlbl. für Bakt. Bd. XXVI, 1899, pag. 453.

- - Über die Kultur des Leprabazillus. Zeitschr. für Hyg. Bd. III. 1888.

Bruns H., Ein Beitrag zur Pleomorphie der Tuberkelbazillen. Ctrbl. für Bakt. Bd. XVII. 1895.

- Zur Morphologie der Aktinomyces. Ctrlbl. für Bakt. Bd. XXVI. 1899.

Bütschli, Bemerkungen über Cyanophyceen und Bakterien. Archiv für Protistenkunde Bd. I. 1902.

Coppen Jones, Über die Morphologie und systematische Stellung des Tuberkelpilzes und über die Kolbenbildung bei Aktinomykose und Tuberkulose. Ctrbl. für Bakt. Bd. XVII. 1895.

- U Über einen neuen bei Tuberkulose häufigen Fadenpilz. Ctrlbl. für Bakt. Bd. XIII. 1893.

Czaplewski, Zum Nachweis der Tuberkelbazillen im Sputum. Ctrbl. für Bakt. 1890 , pag. 685 urd 717.

- Zur Kenntnis der Smegmabazillen. Med. Wochenschr. 1897 Nr. 43.

- Ü̈ber einen aus einem Leprafalle gezüchteten alkohol- und säurefesten

Bazillus aus der Tuberkelbazillengruppe. Ctrlbl. für Bakt. Bd. XXIII, 1898, pag. 97 und 189.

- Die Untersuchung des Auswurfs auf Tuberkelbazillen. Jena 1891.

De jcke-Pascha und Reschad-Bey, Neue Gesichtspunkte in der Leprafrage.

Deutsche med. Wochenschr. Nr. 13.

Ernst P., Über den Bazillus xerosis und seine Sporenbildung. Zeitschr. für Hyg. Bd. IV.

- - Über Kern- und Sporenbildung in Bakterien. Zeitschr. für Hyg. Bd. V pag. 428.

- Über den Bau der Bakterien. Ctrlbl. für Bakt. Bd. VIII. 1902.

Feinberg, Über den Bau der Bakterien. Ctrlbl. für Bakt. Bd. XXVII.

Ficker M., Zur Frage d. Körnchen u. Kerne d. Bakterien. Archiv f. Hyg. Bd. XLVI.

Fischel, F., Untersuchungen über Morphologie und Biologie des Tuberkulose-

erregers. Fortschr, der Medizin Bd. X. 1893. 
Fischel F., Zur Morphologie und Biologie des Tuberkuloseerregers. Berl. klin. Wochenschrift 1893 Nr. 41.

Fischer A., Untersuchungen über den Bau der Cyanophyceen und Bakterien, Jena 1897.

- Fixierung, Färbung und Bau des Protoplasmas. Jena 1899.

- Untersuchungen über Bakterien. Pringsheims Jahrb. Bd. XXVII Heft I. 1894.

- Vorlesungen über Bakterien. 1897.

Flügge, Die Mikroorganismen. 1896.

Fraenkel, Zur Kenntnis der Smegmabazillen. Ctrlbl. für Bakt. Bd. XXIX, 1901, pag. 3.

Friedrich, Über strahlenpilzähnliche Wuchsformen des Tuberkelbazillus im Tier-

körper. Deutsche med. Wochenschr. Nr. 41. 1897.

Grimme, Die wichtigsten Methoden der Bakterienfärbung. Ctrlbl. für Bakt. 1902. Hegler, Untersuchungen über die Organisation der Phycochromaceenzelle. Jahrb. für wiss. Botanik Bd. XXXVI. 1901.

Hellström, Über Tuberkelbazillennachweis in Butter etc. Ctrbl. für Bakt. XXVIII, 1900, pag. 542.

Herr, Ein Beitrag zum Verhalten der Tuberkelbazillen bei Überimpfung auf Blindschleichen. Zeitschr. für Hyg. 1901 pag. 198.

- Ein Beitrag zur Verbreitung der säurefesten Bakterien. Zeitschr. für Hyg. 1901, pag. 201.

Herr und Berinde, Untersuchungen über das Vorkommen von Tuberkelbazillen in der Butter. Zeitschr. für Hyg., 1901, pag. 152.

Hormann und Morgenroth, Über Bakterienbefunde in der Butter. Hyg. Rundschau 1898, pag. 217.

- - Weitere Mitteilungen über Tuberkélbazillen in Butter und in Käse. Hyg. Rundschau 1898, Nr. 22.

Karlinski J., Zur Kenntnis der sãurefesten Bakterien. Ctrlbl. für Bakt. Bd.XXIX, 1901, pag. 521.

Kedrowski, Kultur der Lepraerreger. Zeitschr. für Hyg. Bd. 37.

Klein E., Ein weiterer Beitrag zur Aetiologie der Diphtherie. Ctrlbl. für Bakt. Bd. 7. 1890.

Klein, Zur Geschichte des Pleomorphismus des Tuberkuloseerregers. Ctrbl. für Bakt. 1892 Bd, 12.

Koch R., Die Aetiologie der Tuberkulose. Mitteilungen aus dem kaiserlichen Gesundheitsamte Bd. II, 1882, pag. 1.

Koernicke M., Der heatige Stand der pflanzlichen Zellforschung. Berichte der deutschen bot. Gesellsch. 1903.

Kohl, Über die Organisation und Physiologie der Cyanophyceenzelle und die mitotische Teilung ihres Kernes. 1903.

K orn O., Zur Kenntnis der säurefesten Bakterien. Ctrlbl. für Bakt. XXY, 1899, pag. 532.

- - Tuberkelbazillenbefunde in der Marktbutter. Arch. für Hyg. 1899, Bd. XXXVI pag. 57.

- Weitere Beiträge zur Kenntnis der säurefesten Bakterien. Ctrlbl. für Bakt. Bd. XXVI, 1900, pag. 481.

Kossel, Berichte an d. internat. Tuberkulose-Kongrefs, Paris 1905, pag. 118. 
Kossel, Weber und Heufs, Vergleichende Untersuchungen über Tuberkelbazillen verschiedener Herkunft. Tuberkulosearbeiten aus d. kaiserl. Gesundheitsamte H. 1.

- Tuberkulosearbeiten aus d. kaiserl. Gesundheitsamte, 1905, H. 3.

Kutscher, Neuere Arbeiten über die Bakterien der Tuberkelbazillengruppe. Berl.

klin. Wochenschr. Nr. 9. 1905.

Lachner-Sand ova l, Über Strahlenpilze. In.-Diss. Strafsburg 1898.

Lehmann und Neumann, Atlas und Grundrifs der Bakteriologie. 3. Aufl. 1904.

Levy E., Ein neues aus einem Fall von Lepra gezüchtetes Bakterium aus der

Klasse der Tuberkelbazillen. Arch. für Hyg. XXX. 1897.

- Über die Aktinomycesgruppe und die ihr verwandten Bakterien. Ctrlbl, für Bakt. Bd. XXI, 1899, pag. 1.

- Zur Morphologie und Biologie der Tuberkelbazillen. Zeitschr. für klin. Medizin Bd. 55.1904.

Maffucci, Über Geflügeltuberkulose. Zeitschr. für Hyg. XI. 1892.

Marpmann, Zur Morphologic und Biologie der Tuberkelbazillen. Ctrlbl. für

Bakt. Bd. XXII, 1897.

Marx H. und Woithe F., Ctrlbl. für Bakt. Bd. XXVIII.

Marx H., Ctrlbl. für Bakt. Bd. XXVIII.

- Ebenda XXIX.

Matzuschita, Über die Wachstumsunterschiede der Bazillen der Hühner- und der menschlichen Tuberkulose auf pflanzlichen, Gelatine- und Agarnährböden. Ctrlbl. für Bakt. Bd. XXVI. 1899.

- Über die Bakterien in besprengtem und nicht besprengtem Strafsenstaub. Arch. für Hyg. Bd. XXXV, 1899, pag. 252.

Ma yer, Zur Kenntnis der säurefesten Bakterien. Ctrbl. für Bakt. Bd. XXVI.

Metschnikoff, Über die phagocytäre Rolle der Tuberkelriesenzellen. Virchovs Archiv Bd. 113. 1888.

Meyer A., Studium über Morphologie und Entwicklungsgeschichte der Bakterien. Flora Bd. 84. 1897.

- - Über Geifseln, Reservestoffe, Kerne und Sporenbildung bei Bakterien. Flora Bd. 86. 1899.

- - Praktikum der botanischen Bakterienkunde. 1903.

Migula, System der Bakterien. Jena 1897.

Moeller $\Lambda$., Über dem Tuberkelbazillus verwandte Mikroorganismen. Therapeutische Monatshefte 1898 pag. 607.

- Ein neuer säure- und alkoholfester Bazillus aus der Tuberkelbazillengruppe, welcher echte Verzweigungsformen bildet. Ctrlbl. für Bakt. Bd. XXV, 1899, pag. 369.

- Ü̈ber die Beziehungen der Tuberkelbazillen zu den anderen säurefesten Bakterien und zum Strahlenpilze. Ctrlbl. für Bakt. Bd. XXX, 1901, pag. 513.

- Zur Verbreitungsweise der Tuberkelpilze. Zeitschr. für Hyg. Bd. XXXII, 1899, pag. 205.

Morgenroth, Über das Vorkommen von Tuberkelbazillen in der Margarine. Hyg. Rundsch. 1899.

Nakanishi, Über den Bau der Bakterien. Ctrlbl. für Bakt. Bd. XXX.

Nei sser A., Zeitschr. für Hyg. Bd. IV.

Noisser M., Ebenda Bd. XXIV. 
Neufeld L., Beitrag zur Kenntnis der Smegmabazillen. Arch. für Hyg. Bd. 39. 1900.

Neukirch, Über Aktinomyceten. Dissertation, Strafsburg 1902.

van Niessen, Zeitschr. für Hyg. Bd. 50. 1905.

Nocard et Roux, Sur la culture du bacille de la tuberculose. Ann. de l'Inst. Pasteur. 1887.

Ob ermüller, Über Tuberkelbazillenbefunde in der Marktbutter. Hyg. Rundschau 1895.

- Neuere Untersuchungen über das Vorkommen echter Tb.-Erreger in der Milch und den Molkereiprodukten. Hyg. Rundschau. 1900.

Petri, Zum Nachweis der Tb.-Bazillen in Butter und Milch. Hyg. Rundschau. 1897.

- Arbeiten aus dem kaiserl. Gesundheitsamte Bd. IV. 1898.

Potet M., Etude sur les bactéries dites „Acidophiles“, les paratuberculibacilles. Lyon 1902.

Rabinowitsch L., Deutsche med. Wochenschr. 1900 Nr. 16.

- Zeitschr. für Hyg. Bd. XXVI. 1897.

- Berl. klin. Wochenschr. 1904.

Rabinowitch, Nitteilung an d. internat. Tuberkulose-Kongrefs. Paris 1905.

Ravenel, Berichte an d. internat. Tuberkulose-Kongrefs, Paris 1905, pag. 135.

Röm er , Tuberkelbazillenstämme. Beiträge zur exper. Therapie Heft 6. 1903.

Ruzička, Über die biologische Bedeutung der färbbaren Körnchen des Bakterien-

inhaltes. Arch. für Hyg. Bd. 47.

- Weitere Untersuchungen über den Bau und die allgemeine biologische Natur der Bakterien. Arch. für Hyg. Bd. 51 Heft 3.

Sauder, Über das Wachstum von Tb.-Bazillen auf pflanzlichen Nährböden. Arch. für Hyg. Bd. XXVI.

Schaudinn, Archiv für Protistenkunde Bd. I.

Schulze, Untersuchungen über die Strahlenpilzformen des Tb.-Erregers. Zeitschr. für Hyg. XXXI.

Silberschmidt, Über Aktinomykose. Zeitschr. für Hyg. Bd. XXXVIII. 1901. Spengler, Zeitschr. für Hyg. 1905 Bd. 49.

Stolz A., Über einen Bazillus mit Verzweigungen. Arch. für Hyg. Bd. 30. 1897. จ. Tave1, Vergleichende Morphologie der Pilze. 1892.

Thellung, Ctrlbl. für Bakt. Bd. 32.

Tobler M., Beitrag zur Frage des Vorkommens von Tb.- und anderen säurefesten Bazillen in der Marktbutter. Zeitschr. für. Hyg. Bd. 36. 1901.

Weber, Arbeiten aus dem kaiserl. Gesundheitsamte Bd. 29. 1902.

Weber und Bofinger, Tuberkulosearb. aus d. kaiserl. Gesundheitsamte Heft 1 . 1904.

Zettnow, Zeitschr. für Hyg. Bd. XXXVIII.

Ziehl, Zur Färbung der Tb.-Bazillen. Deutsche med. Wochenschr. 1888.

- - Über die Färbung der Tb.-Bazillen. Ibidem. 1883.

Zi emann, Ctrlbl. für Bakt. Bd. XXIV.

Zopf, Die Spaltpilze. 2. Auflage. 1884.

Zupnik L., Zeitschr. für Hyg. 1905 Bd. 49. 